\title{
RESEARCH
}

Open Access

\section{Ecological and floristic study of Hirmi woodland vegetation in Tigray Region, Northern Ethiopia}

\author{
Mehari Girmay ${ }^{1,2^{*}}$ (D), Tamrat Bekele ${ }^{2}$, Sebsebe Demissew ${ }^{2}$ and Ermias Lulekal ${ }^{2}$
}

\begin{abstract}
The dryland area in Ethiopia covers a substantial region endowed with diverse plant resources. However, the landmass has received less attention even if it has high ecological, environmental, and economic uses. The present study was conducted in Hirmi woodland vegetation, which is one of the dryland areas in Ethiopia, with the objective of investigating the floristic composition, plant community types, vegetation structure, communityenvironment relations and its regeneration status. Vegetation and environmental data were collected from 80 sampling plots with a size of $25 \mathrm{~m} \times 25 \mathrm{~m}$ designated as the main plots. Diameter at breast height (DBH), height, basal area, density, vertical structure, importance value index (IVI), and frequency were computed. Species diversity and evenness were analyzed using Shannon diversity and evenness indices. The plant community types and vegetation-environment relationships were analyzed using classification and ordination tools, respectively. A total of 171 vascular plant species belonging to 135 genera and 56 families were recorded. About $5.3 \%$ of the species were endemic and near-endemic to Ethiopia. The highest number of species was recorded in families Fabaceae (16.4\%) and Poaceae (11.7\%) followed by Asteraceae (7.0\%), Combretaceae, Lamiaceae, and Moraceae (3.5\% each). Five plant communities were identified. According to the results from ordination analysis, the floristic composition of these plant communities was significantly affected by altitude, slope, sand, silt, soil organic matter, total nitrogen, and disturbance. The vegetation structure reveals that a large number of individual species was categorized in the lower DBH, frequency, and height classes. The highest Shannon diversity index and evenness values of the study area were 4.21 and 0.95, respectively. Anogeissus leiocarpa, Combretum hartmannianum, Ziziphus mucronata, Terminalia macroptera, and Acacia polyacantha were the species with high IVI. Some endemic plants were in the IUCN red list categories of Ethiopia and Eritrea. The overall regeneration status of the study area was poor because of anthropogenic disturbances and grazing pressures. Although the study area is endowed with high plant species diversity including endemism, it is under poor regeneration status due to various disturbances. To overcome this challenge, integrated management measures including monitoring and application of restoration techniques by taking into consideration the significant environmental factors associated with species diversity as well as observed regeneration status and IUCN threat level of the species are highly recommended.
\end{abstract}

Keywords: Diversity, Dryland, Hirmi woodland, Regeneration status, Plant communities

\footnotetext{
*Correspondence: meharigrm@gmail.com; mehari.girmay@aau.edu.et

'Ministry of Mining and Petroleum of Ethiopia, P.O. Box 486, Addis Ababa, Ethiopia

${ }^{2}$ Department of Plant Biology and Biodiversity Management, Addis Ababa University, P.O. Box 3434, Addis Ababa, Ethiopia
}

\section{Springer Open}

(c) The Author(s). 2020 Open Access This article is licensed under a Creative Commons Attribution 4.0 International License, which permits use, sharing, adaptation, distribution and reproduction in any medium or format, as long as you give appropriate credit to the original author(s) and the source, provide a link to the Creative Commons licence, and indicate if changes were made. The images or other third party material in this article are included in the article's Creative Commons licence, unless indicated otherwise in a credit line to the material. If material is not included in the article's Creative Commons licence and your intended use is not permitted by statutory regulation or exceeds the permitted use, you will need to obtain permission directly from the copyright holder. To view a copy of this licence, visit http://creativecommons.org/licenses/by/4.0/. 


\section{Background}

Terrestrial biodiversity represents the richest diversity in the tropics and near to the equator (Gaston 2000), which seems to be the result of the warm climate, high primary productivity and diverse topography in the region (Field et al. 2009). About $40 \%$ of the global tropical forest area (Mayaux et al. 2005) and 14\% of the total African land surface (Eshete et al. 2011) is covered by the dry woodland vegetation. According to Eshete et al. (2011), 25\% of the natural vegetation in Africa is found in the dry woodland vegetation. Though the dryland area has high ecological, environmental, and economic importance, currently, the vegetation resources in this landmass are facing serious problems due to human interferences and very poor stakeholders' attention compared to the moist vegetation (Muys et al. 2006). Deforestation and habitat degradation in the dryland area resulted several socioeconomic and environmental challenges that bring a strong impact on the capacity of the forests to provide rich ecosystem services (Nyssen et al. 2007). To mitigate these challenges, conservation of biodiversity in the dryland ecosystems has been receiving greater international attention from time to time (CBD 2006; Lemenih and Bongers 2011). Effective conservation activities in dryland forests definitely demand an exhaustive investigation on environmental determinants such as soil properties, elevation, habitat suitability, habitat diversity, and species interaction (Arponen 2012; Yismaw et al. 2014).

Ethiopia shares more than $50 \%$ of the Afromontane region's land areas of Africa which are above $1500 \mathrm{~m}$ (Bekele 1993) as well as an extensive dryland region (Teketay 2001). According to a study conducted by Teketay (2001), about $65 \%$ of the Ethiopia landmass is covered by dryland ecosystems, where $12 \%$ of human and $20 \%$ of livestock populations reside. It is also the center of biodiversity, endemism, and grazing (Mengistu et al. 2005).

The wide ranges of agro-ecologies in northern Ethiopia are covered with dry forests or woodland vegetation types (Georgis 2010). However, due to the rapid human growth and agricultural expansions, there were habitat fragmentation and resource exploitations in these areas. Following the long history of land degradation, many land rehabilitation and conservation programs have been carried out in northern Ethiopia in general, Tigray region in particular. However, inadequate investigation of ecological baseline information makes the effectiveness of biodiversity conservation policy and strategy to fall in a challenge for its implementation as it intends (EFAP 1994; Teketay 2001).

Hirmi woodland is one of the dryland vegetation types with potential remnant vegetation stretched in Northern Ethiopia, Tigray region, north to the Tekeze Rift valley (Hagos et al. 1999). An assessment conducted by the
Ethiopian REDD+ (MEF 2015) secretariat reveals Hirmi woodland is identified as one of the vegetation potential areas that require ecosystem restoration and conservation by the participation of the local community, the government, and other stakeholders. Investigation of plant community types and the driving environmental and anthropogenic factors shaping the existing vegetation of the dryland area could serve as the basis for taking effective conservation measures of the dwindling natural resource (Pimm and Raven 2000; Brooks et al. 2002). There are no earlier investigations done on plant diversity, composition, structure, threats, and regeneration status of the Hirmi vegetation so far. Thus, this study is conducted to fill the existing gap and serve as a tool for running effective conservation and sustainable utilization of the study vegetation.

The objectives of the research were to:

i. examine the floristic composition of Hirmi woodland vegetation;

ii. identify the plant community types of the study vegetation;

iii. assess the vegetation structure of the study area;

iv. examine the relationship between selected environmental determinants and the community types of the study vegetation;

$v$. assess the regeneration status of the study vegetation;

vi. identify existing threats to the Hirmi woodland vegetation.

\section{Materials and methods}

\section{Study area}

Hirmi woodland vegetation is stretched in three districts (Tahtay Koraro, Medebay Zana and Asgede Tsimbla) of Northwest Tigray National Regional Administration, Ethiopia. The area of Hirmi woodland vegetation is found at $1100 \mathrm{~km}$ distance from Addis Ababa (Ethiopian capital) between $13^{\circ} 49^{\prime}-14^{\circ} 04^{\prime}$ latitude and of $38^{\circ} 14^{\prime}-$ $38^{\circ} 25^{\prime}$ longitude, with elevation range between 900 and 2002 m.a.s.l. (Fig. 1). The total area covered with Hirmi woodland vegetation is 30,900 ha (Abebe 2010; Agriculture \& Natural Resource Bureau of North-Western Zone of Tigray Region 2017). The vegetation in the study area is dominated by Combretum-Terminalia and AcaciaCommiphora woodland vegetation types (MEF 2015; Girma 2014). Two climatic zones are identified in the study area, the lowlands $(800-1500 \mathrm{~m})$ and middle altitude ranging from 1501-2002 m (NMSAE 2018). A 20years (1998-2017) climatic data was taken from the nearest Endabaguna metrological station so as to describe the climate of the study area. Analysis of the meteorological data showed that the study area has a maximum and minimum monthly mean temperature of 


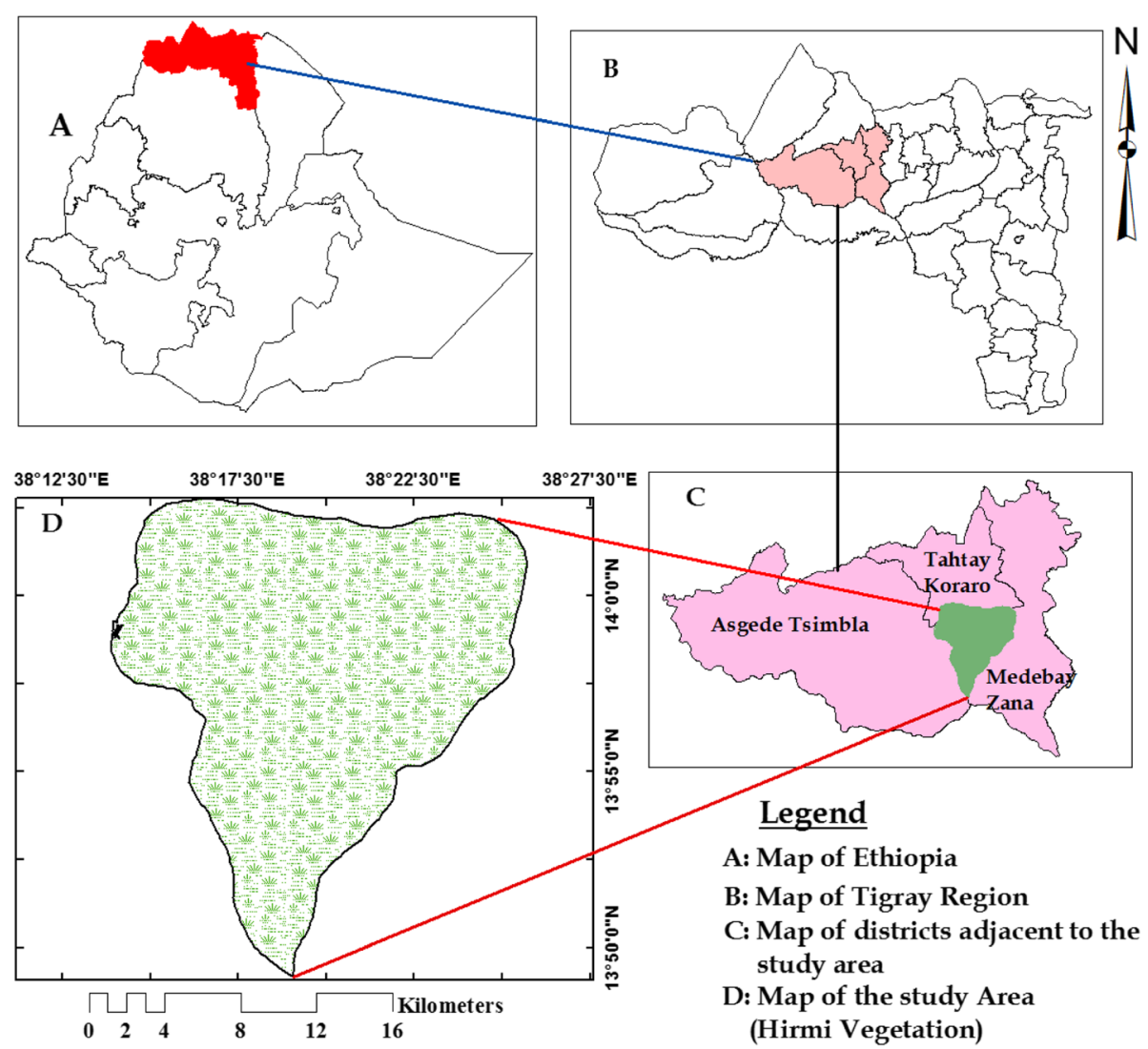

Fig. 1 Map showing position of the study area

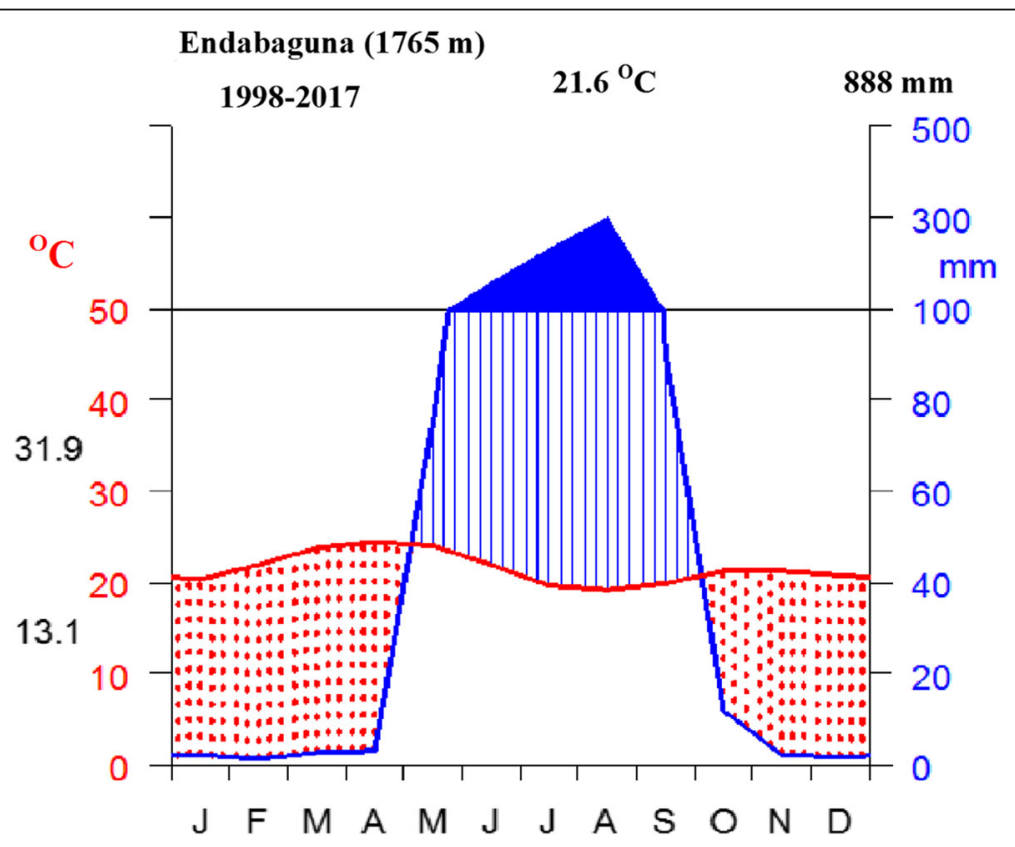

Fig. 2 Climate diagram of the study area (from Endabaguna meteorological station) 
$31.9{ }^{\circ} \mathrm{C}$ and $13.1{ }^{\circ} \mathrm{C}$, respectively. The rainfall of the study site was unimodal with a mean annual of $888 \mathrm{~mm}$. The climate diagram (Fig. 2) showed that the study area receives unimodal rainfall of about $888 \mathrm{~mm} /$ year with high precipitation in August and low precipitation in February.

\section{Method of data collection Vegetation data}

To evaluate and estimate whether the number of species (floristic composition) in the study area has been sufficiently sampled or not, species accumulation curves were plotted using free statistical software $R$ version 3.6.1. Accordingly, vegetation data were collected from a total of 80 plots along 10 transects laid systematically following the sampling approach as described by BraunBlanquet (1964) and Mueller-Dombois and Ellenberg (1974). Each of the plots was laid at every $50 \mathrm{~m}$ altitudinal drop along the transect lines. The distance between each transect ranged from 500 to $700 \mathrm{~m}$ apart. For the collection of woody (shrubs and trees) species, plots of $25 \mathrm{~m} \times 25 \mathrm{~m}\left(625 \mathrm{~m}^{2}\right)$ were laid. Herbaceous species, seedlings, and saplings of all woody plants were recorded in a $2 \mathrm{~m} \times 2 \mathrm{~m}\left(4 \mathrm{~m}^{2}\right)$ subplot inside each main plot, four from each corner and one at the center. Plants with a height of $\geq 2 \mathrm{~m}$ and $\mathrm{DBH} \geq 2 \mathrm{~cm}$ were considered shrubs or trees whereas woody species with height $1-2 \mathrm{~m}$ and height $\leq 1 \mathrm{~m}$ were considered saplings and seedlings, respectively (Senbeta and Teketay 2001; Tuxill and Nabhan 2001; Tadesse 2015). Vegetation coverabundance was estimated based on the Van der Maarel scale (1979).

Plant specimens were collected, pressed, dried properly during the data collection period at the field site, and brought to the National Herbarium, Addis Ababa University for identification and verification. An attempt was also made to record the vernacular names of species encountered in the study during collection whenever possible.

\section{Environmental data collection}

Environmental variables such as altitude, aspect, slope, and geographical coordinates were taken and recorded for each plot. Soil samples were taken from five points (four from each corner and one from the center) measuring $15 \times 15 \mathrm{~cm}$, at a depth of $0-30 \mathrm{~cm}$ (Tenkir 2006; Tadesse et al. 2008) of the main plot laid for vegetation data collection. These samples were mixed to form a composite sample, and about a kilogram of the sample was taken for analysis. The soil samples were air-dried by spreading on plastic trays crushed and sieved with a mesh size of $2 \mathrm{~mm}$ to remove root particles and other organic debris before chemical analyses. Finally, measurements and analysis for soil texture (sand, silt, and clay), $\mathrm{pH}$, electrical conductivity (EC), cation exchange capacity (CEC), soil organic matter (SOM), total nitrogen $(\mathrm{N})$, and available phosphorus $(\mathrm{P})$ were done following the standard procedures outlined in Landon (1991) and Sertsu and Bekele (2000).

Disturbances were recorded as present or absent in the sampled plots. The magnitude of disturbance was rated from 0 to 4 based on visible signs of vegetation disturbance parameters such as tree cutting, debarking, grazing, fire and charcoal production signs following Hadera (2000) and Senbeta et al. (2007). Values were coded as follows: 0: no disturbance; 1: if anyone of the above-mentioned factors was present (slightly disturbed); 2: if any two of the above-mentioned factors were present (moderately disturbed); 3: if any three of the above-mentioned factors were present (highly disturbed); 4: if all of the above-mentioned and other associated natural factors such as tree stumps and landslide/degradation were present (extremely disturbed).

\section{Data analysis \\ Multivariate and diversity analysis}

The study vegetation was classified into community types by the Hierarchical Agglomerative Clustering technique using Ward's method employed in $\mathrm{R}$ packages. The plant community types from the cluster analysis were also analyzed in a synoptic table based on cover-abundance values (van der Maarel 1979). The community was named after the dominant tree or shrub species in that specific community with higher synoptic values. In each plant community type, the synoptic values of each species were further tested to find significant indicator value of the species performed in $\mathrm{R}$ using package labdsv. CCA was used to correlate the identified plant community types with selected environmental and disturbance factors. The reason for using CCA ordination was due to the first axis in the detrended correspondence analysis (DCA) was $>4$ (7.13) and the study was used heterogeneous environmental datasets (Lepš and Šmilauer 2001). In this analysis, environmental factors including altitude, slope, soil physical, and chemical properties $(\mathrm{pH}$, electrical conductivity, soil texture, available phosphorus, soil organic matter, total nitrogen, and cation exchange capacity) as well as disturbance factors (tree cutting, debarking, grazing, fire and charcoal production sign) were assessed and their association with plant community types were investigated.

Shannon index was used to compute species diversity, richness, and evenness of Hirmi vegetation using $\mathrm{R}$ software version 3.6.1 (R Development Core Team 2019) as indicated below:

Shannon diversity index $\left(H^{\prime}\right)$ is calculated from the equation: 


$$
\mathbf{H}^{\prime}=-\sum_{i=\mathbf{1}}^{s} \mathbf{p i} \ln \mathbf{p i}
$$

Shannon evenness index $(J)$ was calculated using the equation:

$$
\mathrm{J}=\frac{\mathbf{H}^{\prime}}{\mathbf{H m a x}}=\frac{\mathbf{H}^{\prime}}{\ln \mathbf{s}}
$$

where $H^{\prime}=$ Shannon diversity index; $\Sigma=$ summation symbol; $\mathrm{pi}=$ the proportion of individuals or the abundance of ith species expressed as a proportional of total cover in the sample and $\ln =\log$ base (natural logarithms); $J=$ evenness; $H_{\max }=\ln S ; S=$ total number of species. $H^{\prime}=0$ if there is only one species in the sample and $H^{\prime}$ is maximum (ranges from 1.5 up to 3.5 and rarely up to 4.5) when all species are represented by the same number of individuals (Kent 2012; Woldu 2016). The values of $J$ ranges normally between 0 and 1 , where 1 represents a situation in which all species are equally abundant (Magurran 1988).

\section{Vegetation structure}

Vegetation structure of the Hirmi woodland vegetation was determined by computing the following parameters.

Diameter at breast height (DBH): $\mathrm{DBH}$ was measured (at $1.3 \mathrm{~m}$ above ground) for trees and shrubs having circumferences $\geq 6 \mathrm{~cm}$ and height $\geq 2 \mathrm{~m}$. For tree/shrub species which branch at breast height or below, DBH of each branch was measured separately and the average was taken and then treated as a single individual for the basal area calculation. There is a direct relationship between DBH and basal area (Kent 2012).

Vertical structure: The vertical structure of the woody species was analyzed using the International Union for Forestry Research Organization (IUFRO) classification scheme (Lamprecht 1989). The IUFRO classification scheme categorizes storey into upper, when the tree/ shrub height is $>2 / 3$ of the top height; middle, for the tree/shrub height between $1 / 3$ and $2 / 3$ of the top height and lower; for the tree/shrub height $<1 / 3$ of the top height.

Basal area (BA) and relative dominance: Basal area of a species is used to calculate species dominance and it is computed from diameter at breast height (d) as follows:

$$
\mathrm{BA}=\pi\left(\frac{\mathrm{d}}{2}\right)^{2}
$$

where; $\pi=3.14$

Frequency: Defined as the probability or chance of finding a species in a given plot. It was computed using the following formula:

$$
\text { Frequency }=\frac{\text { Number of plots where a species occur }}{\text { Total examined plots }} \times 100
$$

Density: refers to the count of individuals per unit area and was computed using:

$$
\text { Density }=\frac{\text { Total number of stems of a given species }}{\text { sample size in hectare }} \times 100
$$

Importance value index (IVI): is useful to compare the ecological significance of species and helps to measure conservation priority among groups of species (Kent 2012). The IVI is the cumulative value of the three parameters (i.e., relative frequency, relative density, and relative dominance), calculated using the following formula:

$$
\begin{aligned}
\mathrm{IVI}= & \text { Relative frequency }(\mathrm{RF}) \\
& + \text { Relative dominance }(\mathrm{RDO}) \\
& + \text { Relative density }(\mathrm{RD})
\end{aligned}
$$

Where,

$$
\begin{aligned}
& \text { Relative frequency }(\mathrm{RF})=\frac{\text { Frequency of a single species }}{\text { Frequency of all species }} \times 100 \\
& \text { Relative density }(\mathrm{RD})=\frac{\text { Density of a single species }}{\text { Total density of all species }} \times 100 \\
& \text { Relative dominance }(\mathrm{RDO})=\frac{\text { Basal area of a single species }}{\text { Total basal area of all species }} \times 100
\end{aligned}
$$

\section{Regeneration status}

Regeneration status was estimated based on the composition and density of seedlings and saplings of all woody species recorded in each plot (Khan et al. 1987). The density of seedlings and saplings were calculated using:

$$
\text { Density of sapling } / \text { seedling }=\frac{\text { the number of sapling/seedling }}{\text { area of sample in a hectare }}
$$

The information on the density of seedlings and saplings is important to take conservation measurements based on their status.

\section{Results}

\section{Floristic composition}

The species accumulation curve graph for the Hirmi vegetation was leveled off as the sampling effort proceeded. This was showing that the rate of discovery to new species would be getting less and less as the further sampling continues (>80 plots). This would be proved that representative samples have been taken to study the floristic composition of the study area. Thus, a total of 171 plant species belonging to 138 genera and 58 families was recorded and identified in the 80 plots of Hirmi woodland vegetation. Regarding the habit of species, herbs, shrubs, trees, and liana were represented by 
79 (46.2\%), 43 (25.2\%), 39 (22.8\%), and 10 (5.8\%) species respectively. The highest number of species was recorded for the families Fabaceae (28 species, 16.4\%) and Poaceae (20 species, 11.7\%) followed by Asteraceae (12 species, 7.0\%), Lamiaceae, Combretaceae, and Moraceae (7 species, 3.5\% each). The remaining 52 families were represented by $\leq 4$ species. Out of the total plant species identified from the study area, $9(5.3 \%)$ species were found endemic (7 species) and near-endemic ( 2 species) to Ethiopia according to the flora of Ethiopia and Eritrea and Friis et al. (2010). Of these, Acacia venosa, Aloe elegans, Bidens macroptera, Lippia adoensis, Pennisetum glaucifolium, Phragmanthera macrosolen and Urtica simensis were endemic and Combretum hartmannianum and Combretum rochetianum were near-endemic species. Based on the IUCN criteria of threat level, one species (Acacia venosa) was recorded as endangered, while two species (Combretum hartmannianum and Combretum rochetianum) were designated as vulnerable and the remaining endemic species were identified as least concern and not evaluated (Table 1).

\section{Plant community types}

Five plant community types were identified from the agglomerative hierarchical cluster analysis (Ward's method) based on the abundance data of the species on the study plots (Fig. 3). Two species with relatively high synoptic and significant indicator values in the group were used to name the corresponding communities (Table 2). The descriptions of the community types identified from the study vegetation are given below.

\section{Ziziphus mucronata-Acacia polyacantha community type}

The altitudinal ranges of this community were from 1170-1565 m.a.s.l. At the edge and lower altitude of the community, high disturbance signs such as cutting, debarking, grazing were documented. In contrast to other community types, this community was situated at a moderate slope which ranges from $2-35 \%$. The shrub and tree layers in this community type were undifferentiated. Ziziphus mucronata and Acacia polyacantha were characteristics species of the community. The common tree species in this community were Acacia polyacantha, Ficus ingens, Terminalia macroptera, Entada abyssinica and Lonchocarpus laxiflorus whereas Ziziphus mucronata, Ziziphus spina-christi, Flueggea virosa, Dichrostachys cinerea, and Senna obtusifolia were the among dominant shrub species. The common species in the field (herb) layer were Bidens pilosa, Achyranthes aspera, Chamaecrista mimosoides, Trifolium campestre, and Setaria megaphylla.

\section{Combretum hartmannianum-Terminalia macroptera community type}

This community was found within the altitudinal range of 1098-1300 m.a.s.l. at the south edge of the vegetation. It was the most disturbed community. The community was dominated by undifferentiated Combretum and Terminalia species. Combretum hartmannianum and Terminalia macroptera were the characteristic tree species in the community. Species including Lonchocarpus laxiflorus, Ficus ingens, Anogeissus leiocarpa, and Combretum rochetianum were also commonly found in the tree layer. Lannea fruticosa was the characteristic species in the shrub layer. Grewia ferruginea and Flueggea virosa were other prominent shrub species in the community. The Oxytenanthera abyssinica community in the study area is found in this community type. It was recorded almost in all plots (in 10/11 plots) of the community (Fig. 4). Setaria megaphylla and Oplismenus burmannii were the characteristic species in the field layer. Species such as Senna obtusifolia, Setaria megaphylla, Oplismenus burmannii, Acanthospermum

Table 1 Endemic species and their IUCN status (ED endemic, NE near-endemic, $H$ herb, $S$ shrub, $T$ tree, $L C$ least concern, EN endangered, NE not evaluated, $V U$ vulnerable)

\begin{tabular}{|c|c|c|c|c|c|c|}
\hline No. & Species name & Family & Endemicity & Habit & Local name & IUCN category \\
\hline 1 & Acacia venosa Hochst. ex Benth. & Fabaceae & ED & S & Kentib & EN \\
\hline 2 & Aloe elegans Tod. & Aloaceae & ED & S & Ere & LC \\
\hline 3 & Bidens macroptera (Sch. Bip. ex Chiov.) Mesfin Tadesse & Asteraceae & ED & H & Gelgelemeskel & $\mathrm{NE}$ \\
\hline 4 & Combretum hartmannianum Schweinf. & Combretaceae & NE & $\mathrm{T}$ & Seabea & $\mathrm{VU}$ \\
\hline 5 & Combretum rochetianum A. Rich. ex A. Juss. (near endemic) & Combretaceae & NE & $\mathrm{T}$ & Afekumo & $\mathrm{VU}$ \\
\hline 6 & Lippia adoensis Hochst. ex Walp. & Verbenaceae & ED & S & Keskese & LC \\
\hline 7 & Pennisetum glaucifolium Hochst. ex A. Rich. & Poaceae & ED & H & - & NE \\
\hline 8 & Phragmanthera macrosolen (A. Rich.) M. Gilbert & Loranthaceae & ED & S & Dikala lihay & NE \\
\hline 9 & Urtica simensis Steudel & Urticaceae & ED & $\mathrm{H}$ & Tsehaytu & LC \\
\hline
\end{tabular}




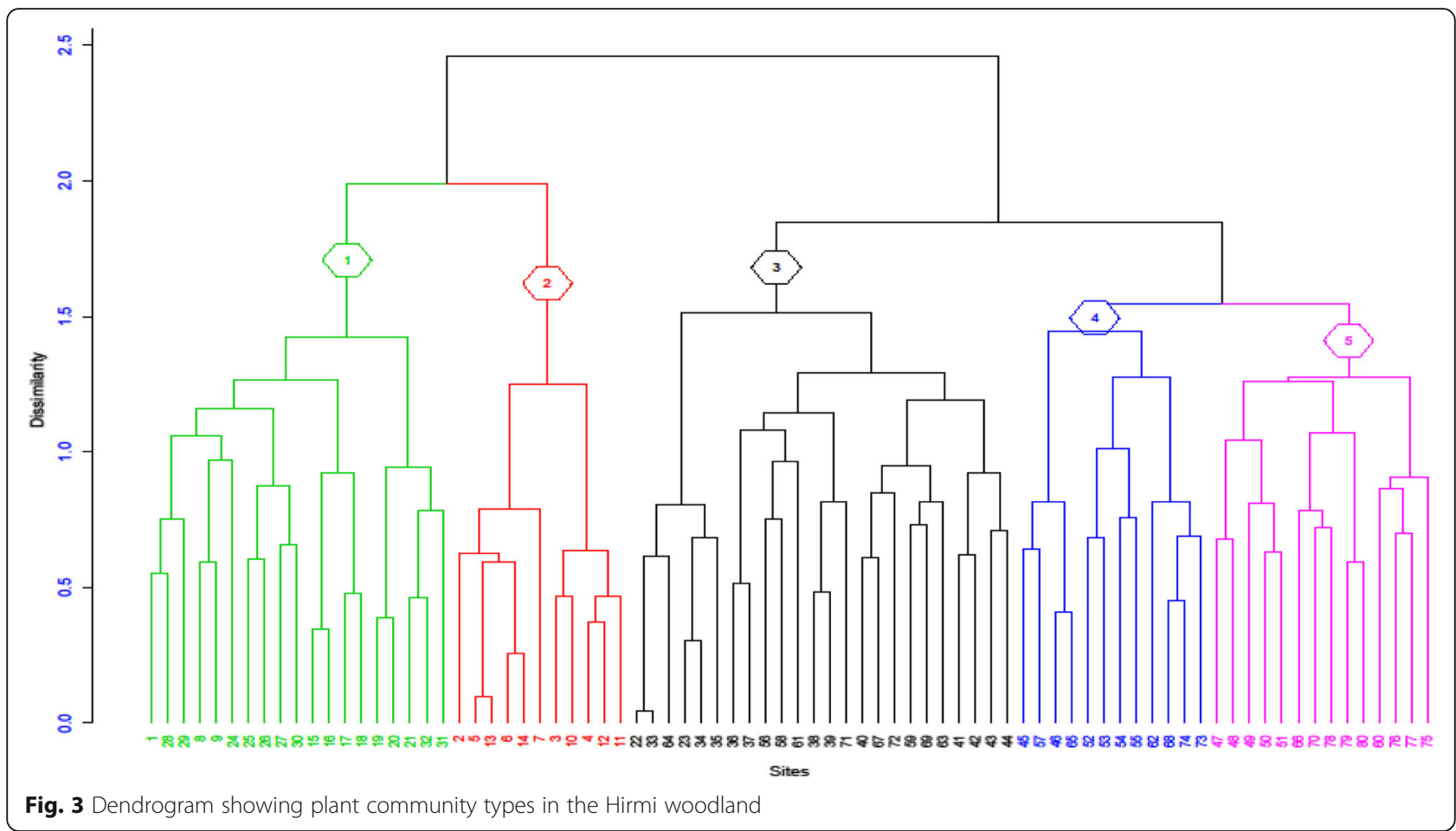

hispidum, and Bidens pilosa were also commonly found in the field layer.

3. Anogeissus leiocarpa-Ozoroa insignis community type

This community was found within an altitudinal range of $1400-1840$ m.a.s.l. with an average slope of $41 \%$. The majority $(87.5 \%)$ of the plots were taken from (near to) the center of the study vegetation. It was a relatively species-rich community harboring 100 species. Anogeissus leiocarpa, Ozoroa insignis, and Terminalia laxiflora were the characteristic species in the tree layer. The community was dominated by tree species including Anogeissus leiocarpa, Ozoroa insignis, Acacia abyssinica, Terminalia laxiflora and Combretum hartmannianum. Bidens macroptera, Guizotia scabra, Bidens pilosa, Oplismenus burmannii, and Eleusine africana were among the species in the field layer that were codominant with the tree layers. Although there were no prominent species in the shrub layer, however, species such as Vangueria madagascariensis, Rhus retinorrhoea, and Acokanthera schimperi were among the common shrub species in the community.

4. Euclea racemosa-Acacia abyssinica community type

This community type was found in the altitudinal range between 1405 and 2002 m.a.s.l. and on gentle to strong slopes (8-75\%). In other words, the highest altitudes and strongest slopes of the study area were situated in this community. Balanites aegyptiaca, Combretum molle, Ximenia americana, Ficus salicifolia, and Justicia schimperiana were species at the lower altitudes of the community type. At the upper altitudes (>1800 m.a.s.l) plant species that belong to the DAF vegetation type (Friis et al. 2010) such as, Olea europaea subsp. cuspidata, Acacia lahai, Acacia abyssinica, Croton macrostachyus, Erythrina abyssinica, and Calpurnia aurea were recorded. The community was dominated by shrub species that include Euclea racemosa, Galiniera saxifraga, Acokanthera schimperi, Acacia seyal, Rhus retinorrhoea, and Diospyros abyssinica. Out of those Euclea racemosa, Galiniera saxifrage and Acokanthera schimperi were the characteristic species in the shrub layer. Acacia abyssinica and Combretum molle were the characteristic and dominant species in the tree layer. Although no prominent herb species were recorded for this community, few individual herbaceous species including Bidens macroptera, Bidens pilosa, and Desmodium repandum were recorded.

\section{Dodonaea angustifolia-Flueggea virosa community type}

This community occurs at altitudes from 1285 to 1790 m.a.s.l. Various disturbances (cutting, grazing, and fire) were recorded in most of the sampled plots. In the elevated and moderate slopes of the community, two 
Table 2 Species list with synoptic cover-abundance values for species having a value of $\geq 1$ at least one in a community type

\begin{tabular}{|c|c|c|c|c|c|c|}
\hline Community number & $\mathrm{C1}$ & $\mathrm{C} 2$ & C3 & C4 & $\mathrm{C5}$ & \\
\hline Community size & 19 & 11 & 24 & 12 & 14 & $P$ value \\
\hline Ziziphus mucronata & 3.37 & 0.27 & 0.21 & 0 & 1.29 & 0.004 \\
\hline Acacia polyacantha & 3.21 & 0.73 & 0 & 0 & 0.34 & 0.001 \\
\hline Bidens pilosa & 2.11 & 2 & 1.5 & 0.67 & 0.29 & 0.12 \\
\hline Achyranthes aspera & 1.89 & 0 & 0.17 & 0 & 0 & 0.012 \\
\hline Ziziphus spina-christi & 1.74 & 0.27 & 0.62 & 0.17 & 0.93 & 0.06 \\
\hline Trifolium campestre & 1.84 & 0 & 0 & 0.33 & 1.43 & 0.6 \\
\hline Chamaecrista mimosoides & 1.68 & 0 & 0.33 & 0 & 1.14 & 000 \\
\hline Dichrostachys cinerea & 1.26 & 0.73 & 0 & 0 & 0.36 & 000 \\
\hline Combretum hartmannianum & 0.84 & 5.64 & 0.92 & 0 & 0.71 & 0.01 \\
\hline Terminalia macroptera & 1.32 & 4.09 & 0.42 & 0 & 0 & 000 \\
\hline Setaria megaphylla & 0.84 & 4 & 0.33 & 0 & 0.57 & 000 \\
\hline Oxytenanthera abyssinica & 0 & 3.91 & 0 & 0 & 0 & 0 \\
\hline Oplismenus burmannii & 0.63 & 3.27 & 0.83 & 0 & 0 & 000 \\
\hline Ficus ingens & 1.05 & 2.64 & 0 & 0 & 0 & 0.615 \\
\hline Senna obtusifolia & 1.05 & 2.55 & 0 & 0 & 0 & 0.05 \\
\hline Lannea fruticosa & 0.53 & 1.45 & 0.33 & 0 & 0.36 & 000 \\
\hline Acanthospermum hispidum & 0.84 & 1.09 & 0.33 & 0 & 0.29 & 000 \\
\hline Eleusine africana & 0.79 & 1.09 & 0.96 & 0 & 0 & 0.01 \\
\hline Anogeissus leiocarpa & 1.58 & 2.64 & 2.96 & 0 & 0 & 000 \\
\hline Ozoroa insignis & 0 & 0.88 & 2.79 & 0 & 2.29 & 000 \\
\hline Bidens macroptera & 0.42 & 0 & 2.33 & 1.33 & 0.86 & 0.38 \\
\hline Guizotia scabra & 0.21 & 0 & 2.12 & 0.33 & 0.86 & 0.45 \\
\hline Terminalia laxiflora & 0 & 0 & 1.46 & 0 & 0.79 & 000 \\
\hline Vangueria madagascariensis & 0 & 0 & 1.17 & 0.42 & 0.14 & 0.23 \\
\hline Rhus retinorrhoea & 0.32 & 0 & 0.58 & 1.67 & 0 & 000 \\
\hline Diospyros abyssinica & 0.26 & 0 & 0.54 & 1.33 & 0.43 & 0.01 \\
\hline Combretum molle & 0.32 & 0 & 0.46 & 1 & 1.14 & 000 \\
\hline Entada abyssinica & 1.21 & 0 & 0.21 & 0 & 0.36 & 000 \\
\hline Eucle racemosa & 0 & 0 & 0.21 & 3.17 & 0.71 & 000 \\
\hline Acacia abyssinica & 0 & 0 & 1.75 & 2.83 & 1.21 & 000 \\
\hline Galiniera saxifraga & 0 & 0 & 0.42 & 2.25 & 0.79 & 0.01 \\
\hline Acokanthera schimperi & 0.37 & 0 & 0.29 & 2.08 & 0 & 000 \\
\hline Acacia seyal & 0 & 0 & 0.75 & 1.83 & 1.21 & 000 \\
\hline Balanites aegyptiaca & 0.11 & 0 & 0 & 1.75 & 0 & 0.81 \\
\hline Mimusops kummel & 0.26 & 0 & 0.42 & 1.5 & 0.36 & 0.11 \\
\hline Acacia lahai & 0 & 0 & 0.25 & 1.42 & 0.79 & 000 \\
\hline Desmodium repandum & 0 & 0 & 0.17 & 1.08 & 0 & 000 \\
\hline Dodonaea angustifolia & 0 & 0 & 2.0 & 1.33 & 3.71 & 0.01 \\
\hline Flueggea virosa & 1.68 & 0.91 & 0 & 0 & 1.36 & 0.02 \\
\hline Hyparrhenia cymbaria & 0 & 0 & 0 & 0 & 1.71 & 0.612 \\
\hline Hyparrhenia rufa & 0 & 0 & 0.17 & 0 & 1.43 & 0.134 \\
\hline Capparis tomentosa & 0.21 & 0 & 0.21 & 0.17 & 1.07 & 0.16 \\
\hline Arthraxon micans & 0 & 0 & 0.17 & 0 & 1.43 & 000 \\
\hline
\end{tabular}


Table 2 Species list with synoptic cover-abundance values for species having a value of $\geq 1$ at least one in a community type (Continued)

\begin{tabular}{|c|c|c|c|c|c|c|}
\hline Community number & C1 & $\mathrm{C} 2$ & C3 & $\mathrm{C} 4$ & C5 & \\
\hline Dactyloctenium aegyptium & 0 & 0 & 0.83 & 0.33 & 1.14 & 000 \\
\hline Grewia ferruginea & 0.26 & 2.18 & 0.29 & 0 & 0.71 & 1.00 \\
\hline Combretum adenogonium & 1.11 & 0 & 0 & 0 & 0 & 4.23 \\
\hline Stereospermum kunthianum & 0.26 & 1.09 & 0 & 0 & 0 & 0.84 \\
\hline Lonchocarpus laxiflorus & 0.11 & 2 & 0 & 0 & 0 & 0.145 \\
\hline Combretum rochetianum & 0 & 2.18 & 0 & 0 & 0 & 0.15 \\
\hline
\end{tabular}

*Bold = species score high cover-abundance and significant values ( $P$ value) used for community types

single shrubby species (Dodonaea angustifolia and Flueggea virosa) were recorded with high densities. Besides these characteristics, species Ziziphus mucronata, Capparis tomentosa, and Ziziphus spina-christi were commonly found in the shrub layer. The characteristics and dominant tree species associated in this community were Acacia seyal, Combretum molle, Acacia abyssinica, Ozoroa insignis, and Entada abyssinica. Dominant herbs in the community include species such as Hyparrhenia cymbaria, Trifolium campestre and Hyparrhenia rufa. Arthraxon micans, Chamaecrista mimosoides and Dactyloctenium aegyptium were the characteristics of herb species in the field layer.

\section{Ordination}

The CCA ordination result (Fig. 4) revealed that environmental variables including altitudes, slope, disturbance, soil organic matter, total nitrogen, sand, and silt soil type were significantly associated with community types identified in the Hirmi woodland vegetation. Total nitrogen, disturbances, and sand were positively correlated with the community type one (Ziziphus mucronata-Acacia polyacantha) and two (Combretum hartmannianum-Terminalia macroptera). Community type three (Anogeissus leiocarpa-Ozoroa insignis) was found in scattered form and affected by different factors including soil organic matter, slope, silt, and total

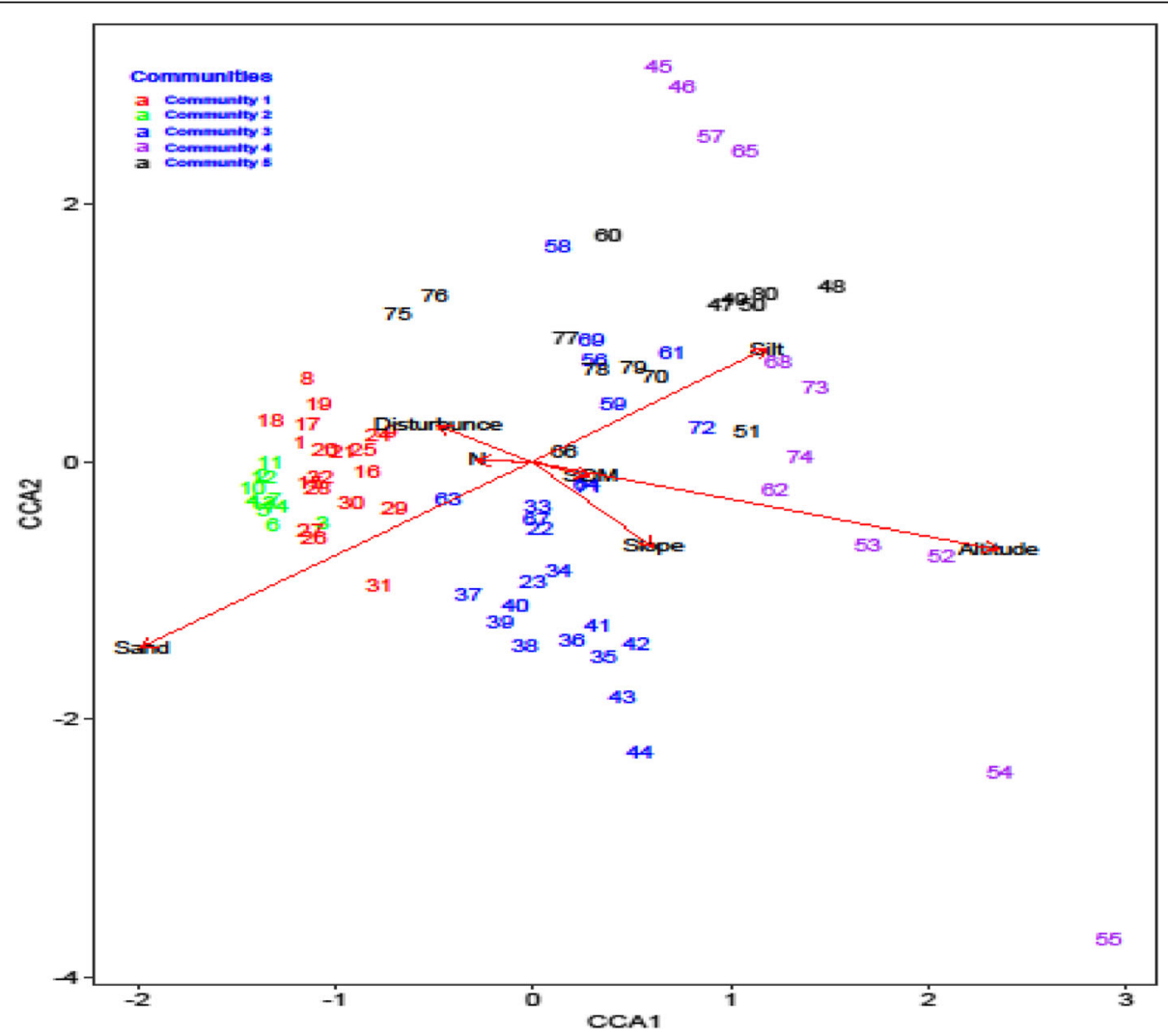

Fig. 4 CCA displaying sites constrained by some selected environmental variables and community types identified by different colors. ${ }^{*} N$ total nitrogen; SOM soil organic matter 
Table 3 The Shannon diversity and evenness indices for the five communities

\begin{tabular}{lllll}
\hline Community & Elevation $(\mathbf{m})$ & $\begin{array}{l}\text { Species } \\
\text { richness }(\mathbf{S})\end{array}$ & $\begin{array}{l}\text { Shannon } \\
\text { diversity index }(\boldsymbol{H})\end{array}$ & $\begin{array}{l}\text { Shannon } \\
\text { evenness index }(\boldsymbol{J})\end{array}$ \\
\hline 1 & $1170-1565$ & 64 & 3.83 & 0.93 \\
2 & $1098-1300$ & 40 & 3.25 & 0.90 \\
3 & $1400-1840$ & 100 & 4.07 & 0.90 \\
4 & $1405-2002$ & 75 & 3.96 & 0.93 \\
5 & $1285-1790$ & 75 & 4.21 & 0.95 \\
\hline
\end{tabular}

nitrogen. However, soil organic matter and silt were highly associated with this community type relatively with other factors. Community number four (Euclea racemosa-Acacia abyssinica) occurred at high altitude, slope, soil organic matter and silt, while community number five (Dodonaea angustifolia-Flueggea virosa) was highly associated with silt and disturbance.

\section{Species richness, evenness, and diversity of the five community types}

Shannon diversity index and evenness of the identified five community types are shown in Table 3 . In terms of the actual number of species per community, community number three (Anogeissus leiocarpa-Ozoroa insignis) was found the most species-rich followed by community number five (Dodonaea angustifolia-Flueggea virosa) and community number four (Euclea racemosa-Acacia abyssinica). Community number two (Combretum hartmannianum-Terminalia macroptera) was the most species-poor community. Similarly, community number five had the highest species diversity $\left(H^{\prime}\right.$ $=4.21$ ) while community number two had the lowest diversity $\left(H^{\prime}=3.25\right)$. In terms of evenness, community $\mathrm{V}$ had the highest evenness index (0.95) and community two and three had the highest similar species or the lowest evenness of species $(0.90$ each) when compared with the other community types.

\section{Vegetation structure}

\section{$D B H$ and height distribution}

Woody species (height $\geq 2 \mathrm{~m}$ and $\mathrm{DBH} \geq 2 \mathrm{~cm}$ ) were classified into seven DBH $(\mathrm{cm})$ classes: $2-10 ; 10.1-20$; 20.130 ; $30.1-40 ; 40.1-60 ; 60.1-80$, and $>80 \mathrm{~cm}$. As the DBH class size increased, the number of individuals was found gradually decreasing towards the successive higher DBH classes (Fig. 5). Sterculia setigera, Ficus vasta, Ficus palmata, Adansonia digitata, and Terminalia laxiflora were found to be the dominant large-sized DBH trees in Hirmi woodland vegetation. Anogeissus leiocarpa, Ziziphus mucronata, and Combretum hartmannianum were among the species which contributed a high cumulative proportion of DBH ( $>14 \%$ of the total DBH), whereas Buddleja cordata, Clerodendrum myricoides, and Otostegia fruticosa contributed the least to the total DBH $(<$ $0.06 \%$ of the total DBH).

Individuals of woody species with height $\geq 2 \mathrm{~m}$ and $\mathrm{DBH} \geq 2 \mathrm{~cm}$ were classified into seven height classes and their densities were calculated. The first two height

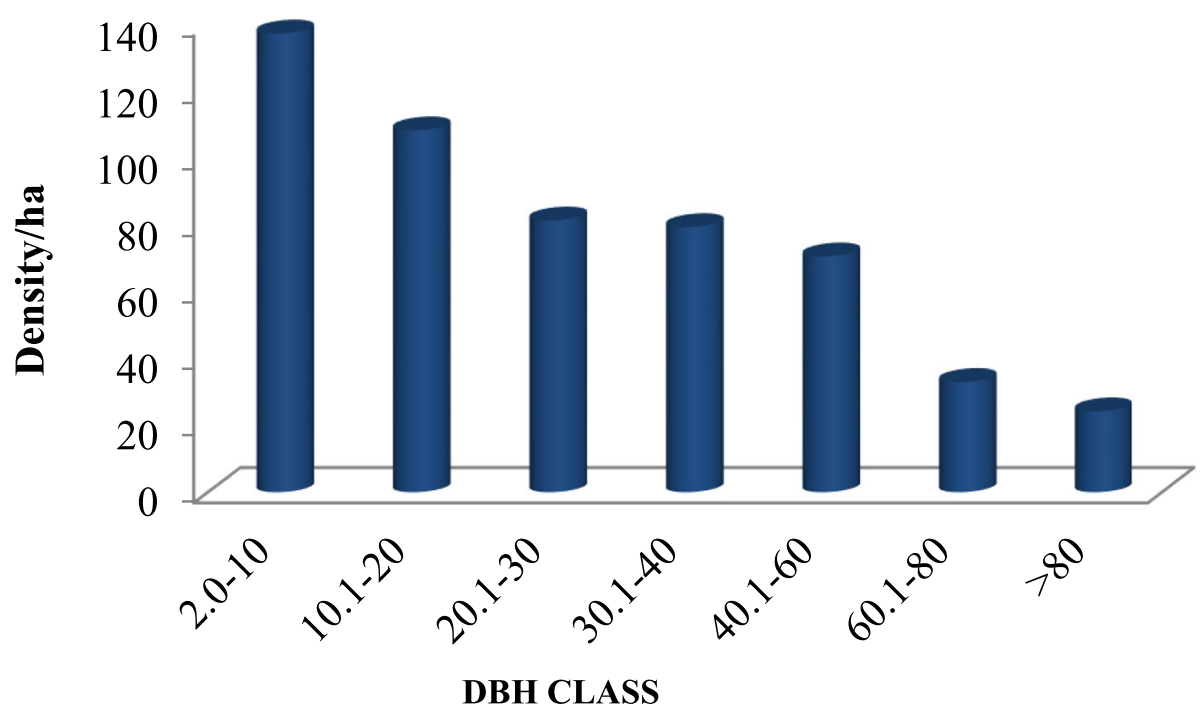

Fig. 5 DBH class distributions of trees and shrubs in the Hirmi woodland 


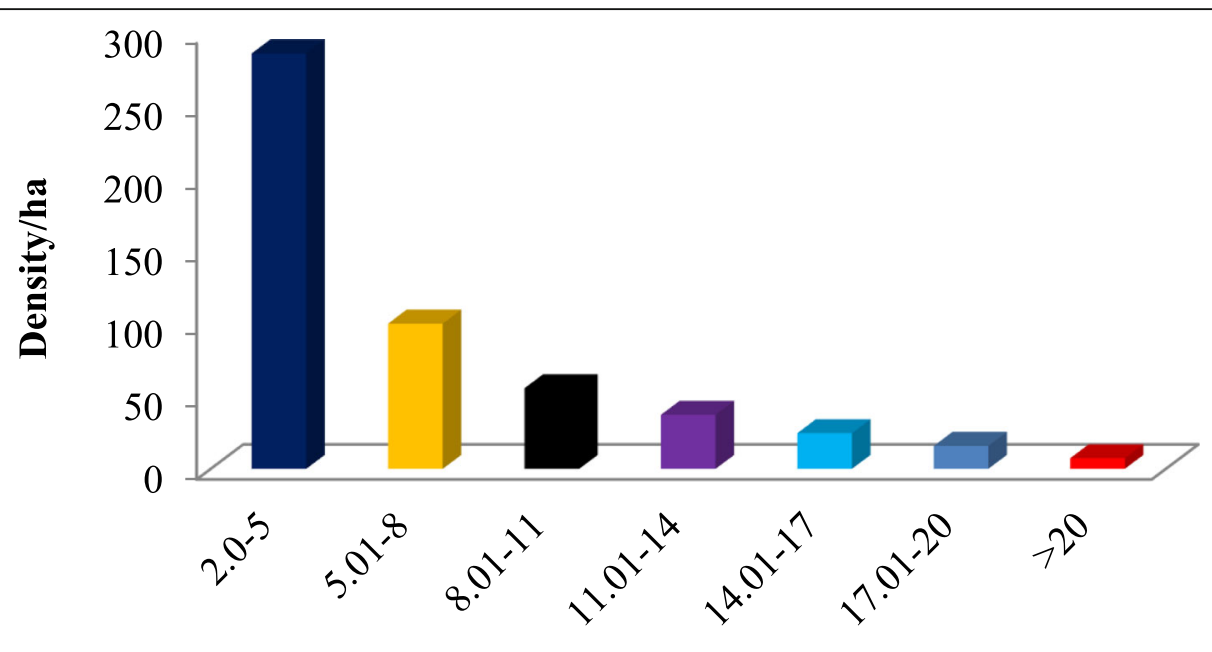

Height class (m)

Fig. 6 Height class distribution of woody species of the Hirmi woodland

classes were accounted for $73 \%$ of the total height class while the remaining five classes were accounted for only $27 \%$ of the total height class. The cumulative height class of Hirmi woodland vegetation has an inverted J-shape which means the decline in the density of woody plants with increasing height classes (Fig. 6).

\section{Vertical structure}

The identified most top height for trees in the Hirmi woodland vegetation was $25 \mathrm{~m}$. According to the IUFRO classification scheme, $65.2 \%$ of the species were in the lower storey $(<8.3 \mathrm{~m})$ followed by the middle $(28.6 \%)$ and upper $(6.2 \%)$ storeys. The lower storey of the Hirmi vegetation was found to contain high numbers of individual species but the upper storey was represented by very few individuals. Woody species present in the lower storey were Acokanthera schimperi, Calpurnia aurea, Dichrostachys cinerea, Dodonaea angustifolia, Flueggea virosa, Maytenus arbutifolia, and Ximenia americana. The wordy plants in the middle storey $(8.3-16.6 \mathrm{~m})$ were Albizia malacophylla, Ziziphus mucronata, Entada abyssinica, Diospyros mespiliformis, and Euclea racemosa. Species such as Acacia albida, Combretum hartmannianum, Stereospermum kunthianum, Acacia abyssinica, Anogeissus leiocarpa, Combretum adenogonium, Ficus vasta, Sterculia setigera, and Terminalia macroptera were among the species categorized in the upper storey $(>16.6 \mathrm{~m})$.

\section{Density of woody species}

A total of 2642 woody species were recorded from 80 plots of the Hirmi woodland vegetation. As indicated in Table 4, only 10 species accounted for $40.4 \%$ of the total density. On the other hand, the remaining woody species altogether accounted for $59.6 \%$ of the total density in the Hirmi woodland.

\section{Basal area (BA) and frequency}

The total basal area of Hirmi woodland vegetation was 14 $\mathrm{m}^{2} \mathrm{ha}^{-1}$. More than $50 \%\left(7.1 \mathrm{~m}^{2} \mathrm{ha}^{-1}\right)$ of the total basal area was contributed by ten large-sized tree species such as Anogeissus leiocarpa, Acacia polyacantha, Combretum hartmannianum, Terminalia macroptera, Ziziphus mucronata, Terminalia laxiflora, Diospyros abyssinica, Ficus ingens, Ozoroa insignis, and Diospyros mespiliformis.

The computed frequency values of species were classified into five frequency classes as: $0-10 \% ; 10.1-20 \%$;

Table 4 Density and percentage contribution of ten woody species in the Hirmi woodland

\begin{tabular}{lll}
\hline Species name & Density ha & (-1 \\
\hline Dodonaea angustifolia & 31.2 & 5.9 \\
Flueggea virosa & 29.2 & 5.53 \\
Diospyros mespiliformis & 28 & 5.3 \\
Anogeissus leiocarpa & 25.8 & 4.88 \\
Ziziphus mucronata & 18 & 3.44 \\
Combretum hartmannianum & 18 & 3.4 \\
Maytenus arbutifolia & 18 & 3.4 \\
Ximenia americana & 16 & 3.03 \\
Acokanthera schimperi & 14.4 & 2.73 \\
Acacia polyacantha & 12.8 & 2.43 \\
Sub-total of 8 species & $\mathbf{2 1 1 . 4}$ & $\mathbf{4 0 . 4}$ \\
The rest species & $\mathbf{3 1 7}$ & $\mathbf{5 9 . 6}$ \\
Total & $\mathbf{5 2 8 . 4}$ & $\mathbf{1 0 0}$ \\
\hline
\end{tabular}




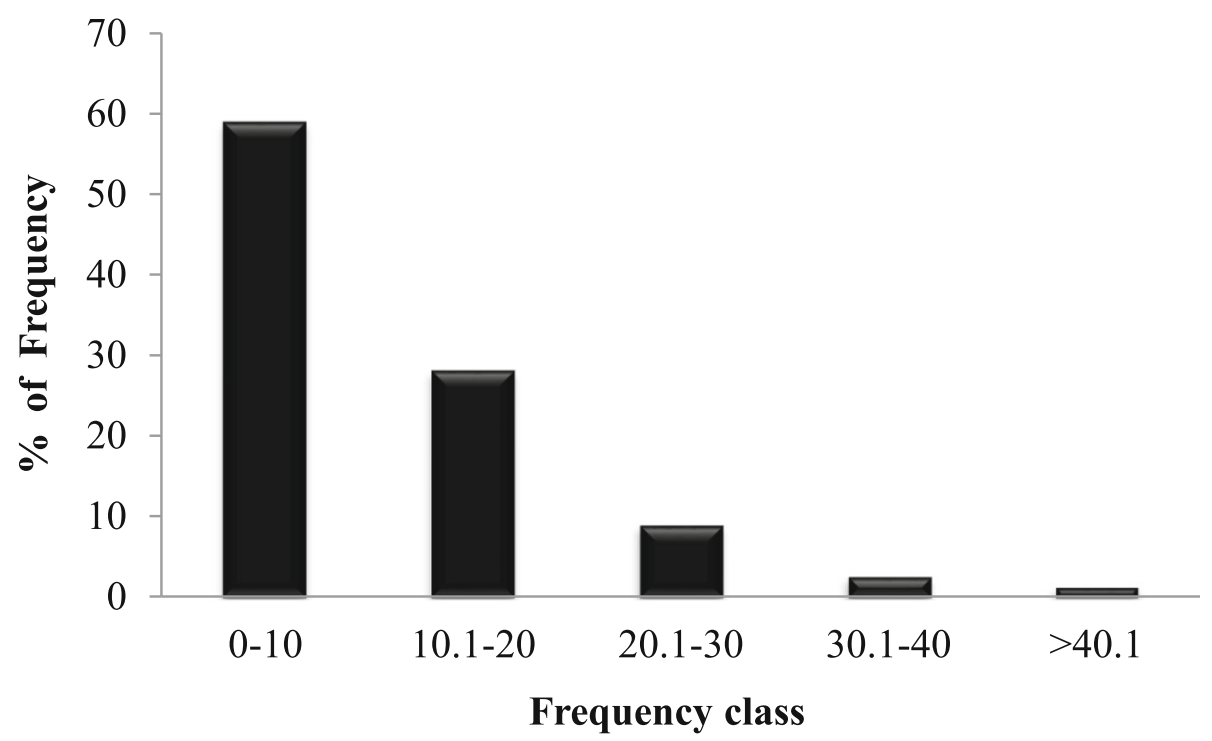

Fig. 7 Frequency distributions of trees and shrubs in the Hirmi woodland

$20.1-30 \%$; $30.1-40 \%$, and $>40 \%$ (Fig. 7). The result showed that $59 \%$ of the total woody species of Hirmi woodland vegetation were distributed in the first frequency class. Besides, the grand frequency distribution of woody species in Hirmi woodland showed that higher proportions of species were distributed in the first frequency class followed by a rapid decline in the distribution of species across successive higher frequency classes. Anogeissus leiocarpa was the most frequent species $(40.5 \%)$, followed by Terminalia macroptera (28.5\%), Ziziphus mucronata, and Combretum hartmannianum (26.25\% each), whereas Acacia nilotica, Olea europaea subsp. cuspidata, Otostegia fruticosa, Phoenix reclinata, Phytolacca dodecandra, and Syzygium guineense were species with low frequencies ( $2.5 \%$ each).

\section{Importance value index (IVI)}

The importance value index of woody species in the study area ranged from 0.35 to 20.55 (Table 5). The first top ten woody species that contribute $37.78 \%$ of the IVI in decreasing order were Anogeissus leiocarpa, Combretum hartmannianum, Ziziphus mucronata, Terminalia macroptera, Acacia polyacantha, Flueggea virosa, Dodonaea angustifolia, Diospyros abyssinica, Ozoroa insignis, and Diospyros mespiliformis. The $62.22 \%$ of the IVI was contributed by the remaining woody species. Some of the species with the least IVI values were Acacia nilotica, Buddleja cordata, Cordia Africana, Olea europaea subsp. cuspidata, Otostegia fruticosa, and Phytolacca dodecandra.

\section{Regeneration status}

The regeneration status of Hirmi woodland was characterized by recording and counting of seedlings, saplings, and adults of trees/shrubs. The total density of seedlings, saplings and mature tree, and shrub species in Hirmi woodland vegetation were $2750 \mathrm{ha}^{-1}, 3025 \mathrm{ha}^{-1}$, and $528.4 \mathrm{ha}^{-1}$ respectively (Fig. 8).

Assessments of seedling and sapling densities were used to prioritize conservation measurement (Table 6). Accordingly, urgent/immediate conservation action is required for those species that fall short in their seedlings and saplings.

\section{Discussion}

Floristic composition and diversity

The result of the species accumulation curve plotted for the species recorded in Hirmi vegetation showed that adequate numbers of plots were laid which was confirmed by the presence of rich species composition (171 species). The majority ( $>85 \%)$ of the study vegetation was composed of Combretum-Terminalia and AcaciaCommiphora woodlands. There is also dry evergreen Afromontane forest (DAF) that component in the massifs and elevated parts of the study area. Besides, herbaceous species that belong to the family Poaceae, Asteraceae, and Fabaceae were predominant in the vegetation of the study area. The existence of high species diversity in the study area could be due to the fact of heterogeneity (existing different vegetation patches) within the vegetation community (Murphy and Lugo 1986), the altitudinal difference (Bekele 1993), anthropogenic impacts (disturbance) (Lyaruu et al. 2000) and soil properties (Kooch et al. 2009). The species richness of Hirmi woodland vegetation is higher than other woodland vegetation in Metema for which 87 species were recorded (Adamu et al. 2012) and more or less equivalent 
Table $\mathbf{5}$ Important value index of woody species of the Hirmi woodland vegetation

\begin{tabular}{|c|c|c|c|c|c|c|c|c|c|}
\hline Species name & $\mathrm{RF}$ & RD & RDO & IVI & Species name & RF & RD & RDO & IVI \\
\hline Anogeissus leiocarpa & 5 & 4.86 & 10.69 & 20.55 & Mimusops kummel & 1.25 & 1.04 & 0.44 & 2.73 \\
\hline Combretum hartmannianum & 3.22 & 3.81 & 6.05 & 13.08 & Acacia lahai & 1.07 & 0.9 & 0.75 & 2.72 \\
\hline Ziziphus spina-christi & 3.22 & 5.24 & 4.28 & 12.74 & Bersama abyssinica & 0.77 & 1.72 & 0.22 & 2.71 \\
\hline Terminalia macroptera & 3.52 & 2.66 & 5.24 & 11.42 & Piliostigma thonningii & 0.92 & 0.52 & 1.03 & 2.47 \\
\hline Acacia polyacantha & 2.45 & 2.36 & 6.42 & 11.23 & Capparis tomentosa & 1.22 & 1.01 & 0.15 & 2.38 \\
\hline Flueggea virosa & 2.3 & 5.46 & 1.92 & 9.68 & Gardenia ternifolia & 1.53 & 0.41 & 0.44 & 2.38 \\
\hline Dodonaea angustifolia & 1.53 & 5.84 & 2.21 & 9.58 & Ficus palmata & 0.77 & 0.34 & 1.25 & 2.36 \\
\hline Diospyros abyssinica & 1.53 & 3.35 & 4.13 & 9.01 & Combretum adenogonium & 0.61 & 0.6 & 0.88 & 2.09 \\
\hline Ozoroa insignis & 2.76 & 1.83 & 3.61 & 8.2 & Adansonia digitata & 1.07 & 0.23 & 0.75 & 2.05 \\
\hline Diospyros mespiliformis & 1.99 & 2.4 & 3.47 & 7.86 & Balanites aegyptiaca & 0.92 & 0.75 & 0.37 & 2.04 \\
\hline Ziziphus mucronata & 3.98 & 2.32 & 1.47 & 7.77 & Boswellia papyrifera & 0.92 & 0.52 & 0.52 & 1.96 \\
\hline Acacia abyssinica & 2.77 & 2.13 & 2.36 & 7.26 & Justicia schimperiana & 0.46 & 0.79 & 0.22 & 1.47 \\
\hline Ficus ingens & 2.3 & 1.04 & 3.61 & 6.95 & Euclea schimperi & 0.77 & 0.49 & 0.15 & 1.41 \\
\hline Terminalia catappa & 1.38 & 1.16 & 4.2 & 6.74 & Ficus vasta & 0.62 & 0.15 & 0.59 & 1.36 \\
\hline Ximenia americana & 2.3 & 3 & 1.4 & 6.7 & Ficus hochstetteri & 0.61 & 0.26 & 0.44 & 1.31 \\
\hline Combretum rochetianum & 1.99 & 1.5 & 2.8 & 6.29 & Acacia albida & 0.61 & 0.3 & 0.38 & 1.29 \\
\hline Acacia seyal & 2.3 & 1.23 & 2.58 & 6.11 & Lannea schimperi & 0.61 & 0.3 & 0.37 & 1.28 \\
\hline Dichrostachys cinerea & 2.3 & 2.28 & 1.32 & 5.9 & Gardenia ternifolia & 0.77 & 0.41 & 0.07 & 1.25 \\
\hline Lannea fruticosa & 2.76 & 1.57 & 1.33 & 5.66 & Leptadenia hastata & 0.62 & 0.49 & 0.07 & 1.18 \\
\hline Acokanthera schimperi & 1.53 & 3.35 & 0.66 & 5.54 & Albizia malacophylla & 0.46 & 0.3 & 0.37 & 1.13 \\
\hline Maytenus arbutifolia & 1.53 & 3.35 & 0.66 & 5.54 & Jasminum abyssinicum & 0.61 & 0.52 & 0 & 1.13 \\
\hline Combretum molle & 1.53 & 1.53 & 1.99 & 5.05 & Woodfordia uniflora & 0.46 & 0.45 & 0.15 & 1.06 \\
\hline Rhus retinorrhoea & 1.84 & 1.8 & 1.25 & 4.89 & Buddleja polystachya & 0.46 & 0.3 & 0.22 & 0.98 \\
\hline Maytenus senegalensis & 1.84 & 2.13 & 0.6 & 4.57 & Strychnos innocua & 0.46 & 0.23 & 0.29 & 0.98 \\
\hline Vangueria madagascariensis & 1.23 & 2.28 & 0.82 & 4.33 & Syzygium guineense & 0.31 & 0.23 & 0.37 & 0.91 \\
\hline Sterculia setigera & 0.91 & 0.37 & 2.95 & 4.23 & Senna singueana & 0.61 & 0.23 & 0.07 & 0.91 \\
\hline Grewia ferruginea & 1.53 & 1.27 & 1.33 & 4.13 & Croton macrostachyus & 0.46 & 0.19 & 0.15 & 0.8 \\
\hline Elaeodendron buchananii & 1.84 & 1.5 & 0.59 & 3.93 & Maerua angolensis & 0.61 & 0.19 & 0 & 0.8 \\
\hline Otostegia integrifolia & 1.07 & 2.21 & 0.37 & 3.65 & Carissa edulis & 0.31 & 0.41 & 0.07 & 0.79 \\
\hline Ficus sycomorus & 1.38 & 0.75 & 1.47 & 3.6 & Erythrina brucei & 0.46 & 0.11 & 0.22 & 0.79 \\
\hline Calpurnia aurea & 0.92 & 1.98 & 0.59 & 3.49 & Albizia amara & 0.46 & 0.19 & 0.07 & 0.72 \\
\hline Euclea racemose & 1.68 & 1.35 & 0.44 & 3.47 & Eugenia bukobensis & 0.46 & 0.19 & 0 & 0.65 \\
\hline Acacia venosa & 1.53 & 1.5 & 0.22 & 3.25 & Phoenix reclinata & 0.31 & 0.15 & 0.15 & 0.61 \\
\hline Entada abyssinica & 1.23 & 0.97 & 0.96 & 3.16 & Cordia africana & 0.31 & 0.11 & 0.07 & 0.49 \\
\hline Ehretia cymosa & 1.23 & 1.23 & 0.66 & 3.12 & Olea europaea & 0.31 & 0.07 & 0.07 & 0.45 \\
\hline Ficus salicifolia & 1.23 & 0.6 & 1.25 & 3.08 & Otostegia fruticosa & 0.32 & 0.11 & 0 & 0.43 \\
\hline Lonchocarpus laxiflorus & 1.23 & 0.79 & 0.81 & 2.83 & Phytolacca dodecandra & 0.31 & 0.11 & 0 & 0.42 \\
\hline Ormocarpum pubescensm & 1.38 & 0.82 & 0.6 & 2.8 & Buddleja cordata & 0.32 & 0.07 & 0 & 0.39 \\
\hline Stereospermum kunthianum & 0.77 & 0.67 & 1.33 & 2.77 & Acacia nilotica & 0.31 & 0.04 & 0 & 0.35 \\
\hline
\end{tabular}

${ }^{*} R F$ relative frequency, $R D$ relative density, $R D O$ relative dominance, $I V I$ importance valueindex; Bold $=$ species with high and least IVI

to that of the Dello Menna woodland vegetation (Didita et al. 2010) but the recorded species richness was less than that of the Ilu Gelan District Combretum-Terminalia mixed Acacia vegetation reported for 214 species
(Tadesse et al. 2018). The recorded high richness of herbaceous species might be attributed to the open canopy cover of the vegetation that enabled for their free growth. This was in agreement with Murphy and Lugo 


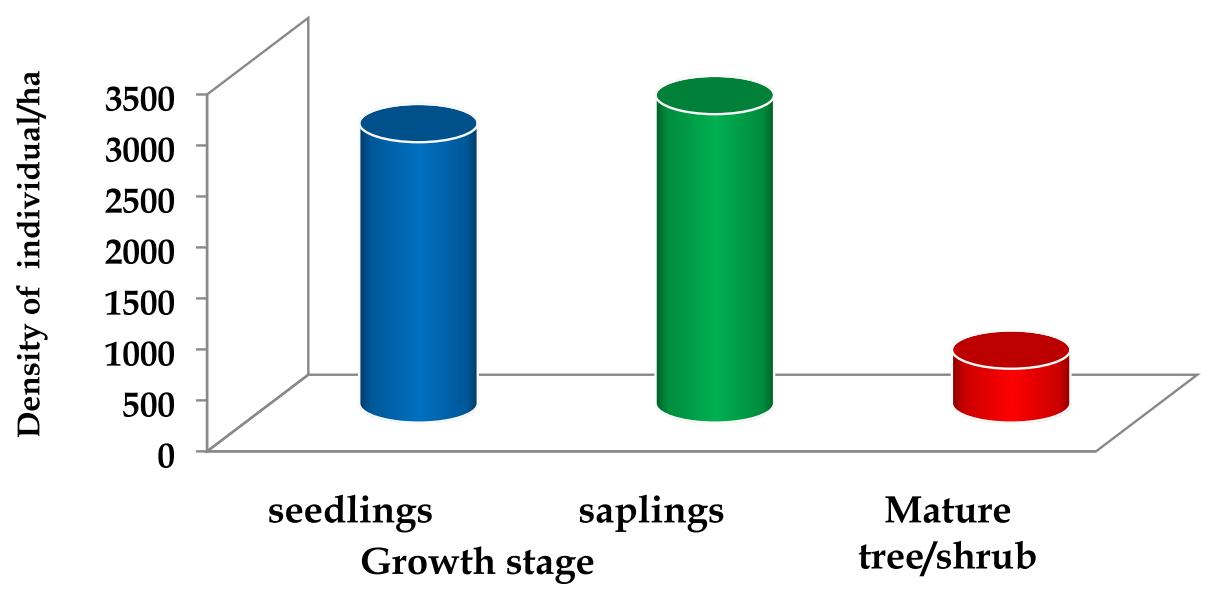

Fig. 8 Density per hectare of seedlings, saplings, mature of woody species (trees/shrubs)

(1986), who reported that an abundance of herbs has an inverse relation with canopy cover. Anthropogenic impacts such as exploiting plant products and selective cutting of trees (Lulekal et al. 2008; Yineger et al. 2008) and dominance of shrubby species in dryland area (Lemenih and Bongers 2011) are also reported as factors responsible for the dominant growth of herbaceous species in an area. More than half $(60 \%)$ of the total recorded plant family were represented by one species only, which indicates the diversity of species in Hirmi woodland vegetation. The presence of high numbers of species for the families Fabaceae, Poaceae, Asteraceae, and Lamiaceae conforms to the fact that they are species-rich families in the flora Ethiopia and Eritrea (Tadesse 2004). Out of the recorded 9 endemic species, Acacia venosa and Lippia adoensis have been included in the IUCN red data list of Ethiopia and Eritrea (Vivero et al. 2005). This could be associated with the existing significant anthropogenic and livestock disturbances in the study area. The dryland vegetation types in Ethiopia are currently under strong environmental stress (Friis et al. 2010). An ecosystem approach of biodiversity conservation and participatory forest management provides an opportunity to conserve large numbers of species that are rare and endemic (Aynekulu 2011; Lemenih and Bongers 2011).

The higher values of Shannon diversity index (4.21) and evenness (0.95) designate that the study area is equipped with high species diversity with more even distribution species within the study plots. This could be associated with the observed topographic and/or altitudinal variation (ranged from 1098-2002 m) and the species richness existing in the study area. In line with this analysis, Suratman (2012) reported that differences in terrain determinants (elevation and slope) cause differences in the soils, water, and microclimate conditions which in turn affect species diversity and adaptability. Magurran (2004) also determine the species richness in

Table 6 Regeneration status classification of woody species for conservation priority

\begin{tabular}{llll}
\hline SN & Species with no seedlings & Species with no saplings & Species with no saplings and seedlings \\
\hline 1 & Acacia nilotica & Acacia nilotica & Acacia nilotica \\
2 & Adansonia digitata & Buddleja cordata & Clerodendrum myricoides \\
3 & Balanites aegyptiaca & Clerodendrum myricoides & Cordia africana \\
4 & Clerodendrum myricoides & Cordia africana & Justicia schimperiana \\
5 & Cordia africana & Ficus vasta & Phoenix reclinata \\
6 & Croton macrostachyus & Justicia schimperiana & Phytolacca dodecandra \\
7 & Erythrina abyssinica & Lannea schimperi & \\
8 & Justicia schimperiana & Maerua angolensis & \\
9 & Phoenix reclinata & Phoenix reclinata & \\
10 & Phytolacca dodecandra & Phytolacca dodecandra & \\
11 & Piliostigma thonningii & Sterculia setigera & \\
\hline
\end{tabular}


an area that has a substantial attribution for species diversity

\section{Plant community and environmental relationship (ordination)}

The relationship between plant communities and environmental variables is important in understanding the plant communities in a given ecosystem (McCune and Grace 2002). Patterns of species community are associated with environmental factors including climate, topography, and soil as well as anthropogenic and livestock disturbances (Whittaker et al. 2003). Ecological studies conducted in Ethiopia by Woldu et al. (1989), Friis (1992), Bekele (1994), Aynekulu (2011), Kelbessa and Girma (2011) and Gebrehiwot et al. (2019) reported the importance of environmental variables (altitude, slope, landscape, disturbances, and soil physical and chemical properties) in shaping plant communities.

CCA analysis result showed that environmental variables including altitude, slope, silt, sand, soil organic matter, total nitrogen, and disturbances are associated with species compositions of plant communities in the Hirmi woodland. However, all those environmental determinants exhibited different effects on the five identified communities. This was in line with a study conducted by Brinkmann et al. (2009) which stated the plant community has its distribution area with a specific combination of environmental variables.

Community number one (Ziziphus mucronata-Acacia polyacantha) and community number two (Combretum hartmannianum-Terminalia macroptera) were strongly influenced by sand and total nitrogen. Nitrogen content of soil has been reported as a major factor limiting species growth and diversity (Brown 2003). Disturbances were also common and significantly affected these communities. The observed disturbance might be related to the vicinity of the two communities close to human settlements (i.e., exposed to edge effect). Disturbance impacts including selective cutting and grazing at the edge of vegetation are frequently revealed (Vieira et.al. 2006).

Anogeissus leiocarpa-Ozoroa insignis (Community number three) was positively correlated with soil organic matter, silt, nitrogen, and slope. This could be related to the fact that soil having a high content of organic matter, nitrogen and moisture-holding capacity of the silt loam soil type is suitable for species growth (Brown 2003; O'Geen 2006). This community was less disturbed and had high species richness due to the fact that plots of the community were taken in sites far from the edge effect and sloping areas. Species found on strong slopes are less disturbed and would be rich in species composition (Tilahun et al. 2011; Gebrehiwot et al. 2019).
In the ordination, the axis altitude was positively correlated with community type number four (Euclea racemosa-Acacia abyssinica). The length of arrows of the environmental determinants in the ordination diagram indicates the strength of their impacts on species composition of plant communities and their distribution (ter Braak 1987). This community was distributed along a wide elevation gradient (1405-2002 m.a.s.l.) and has a high Shannon evenness index (0.93). The altitudinal difference does not only influence the species richness and diversity but also affects the other determinants that play a significant role in their distribution and composition such as the soil texture, atmospheric pressure, moisture, and temperature (Bekele, 1994; Lovett and Wasser 1993). High Shanon diversity $\left(H^{\prime}=4.21\right)$ and evenness $(J$ $=0.95$ ) in community number five (Dodonaea angustifolia-Flueggea virosa) was positively associated with silt loam soil and disturbances. Silt loam soil contains the perfect combination of sand, silt, and clay particles and moisture-holding capacity that supports the growth of virtually all forms of plant life (Ruwanza 2018). The disturbed drylands of Ethiopia are covered by shrubs like Dodonaea angustifolia and secondary forests (Lemenih and Bongers 2011; Woldu et al. 2019).

\section{Vegetation structure}

Height and DBH: the overall height and DBH class distribution showed an inverted J-shape distribution. The existence of a high number of species at the lower DBH and height classes was due to the dominance of a smallsized but a large number of individuals including Dodonaea angustifolia, Flueggea virosa, Maytenus arbutifolia, Acokanthera schimperi, Bersama abyssinica, Ziziphus mucronata, and Ximenia americana. The vegetation has more species that belong to a secondary vegetation type thus lacks a large statured tree. A similar result was reported in Abergele dry woodlands (Eshete et al. 2011), Dawsura-Tembien woodlands (Woldu et al. 2019) and Ilu Gelan Combretum-Terminalia and Acacia vegetation (Tadesse et.al. 2018). In other aspects, large-sized DBH are selectively harvested and diminished their quantity since they are preferable for various human services (Hadera 2000).

Vertical structure: based on the Lamprecht (1989) scheme of classification, the highest proportion of species were concentrated in the lower storey followed by the middle and upper storey. The finding might be associated with the dominance of shrubby and small-sized species composition of the study area. A study by White (1983) reported shrubby layer vegetation is mostly dominated by lower undifferentiated woody species. A similar result was also reported in different woodland vegetation of Ethiopia (Lemessa 2009; Tadesse et.al (2018). 
Density: the overall density of woody species in Hirmi woodland was 528.4 individuals per hectare. This was greater than the density reported from other woodland vegetation studied in Metema, Ethiopia (18.8 stems/ha) (Adamu et al. 2012). However, it was less than the study in woodland vegetation of the Borana lowland (3149 stems/ha) (Dale 2004), dry land vegetation of Welo (3146 stems/ha) (Tadesse et al. 2008) and Shai Hills dryland in Ghana (959/ha) (Swaine et al. 1990). Such variation could be attributed to variations in topographic gradients, habitat preferences and the degree of anthropogenic disturbances (Whittaker et al. 2003).

Basal area: Basal area of the Hirmi woodland $\left(14 \mathrm{~m}^{2} /\right.$ ha) was higher than the study conducted in the Taltalle woodland area $\left(0.44 \mathrm{~m}^{2} / \mathrm{ha}\right)$ (Lemessa 2009). However, it was smaller than other woodland vegetation studied in Sire Beggo woodland vegetation $\left(19.3 \mathrm{~m}^{2} / \mathrm{ha}\right.$ ) (Dibaba $2014)$ and Dirki and Jato woodland $\left(18.95 \mathrm{~m}^{2} / \mathrm{ha}\right)$ (Tadesse 2018). More than $50 \%$ of the total basal area of Hirmi woodland was contributed by a few large-sized tree species. However, the richness of these tree species was far less than the shrub species in Hirmi woodland. An area covered with shrub layers and small DBH individuals would have a small total basal area contribution in contrast to tree species (Murphy and Lugo 1986; Lemenih and Bongers 2011).

Frequency: Based on the analysis of frequency by Lamprecht (1989) of frequency, high value in the lower frequency classes showed a heterogeneous species composition of Hirmi woodland. Anogeissus leiocarpa, Combretum hartmannianum, Terminalia macroptera, Ziziphus mucronata, and Ziziphus spina-christi were among the species with high-frequency values, whereas Phoenix reclinata, Phytolacca dodecandra, Olea europaea subsp. cuspidata, Acacia nilotica, and Cordia africana had small frequency values. The frequency of a species always depends on factors that relate to habitat preferences, adaptation, and degree of exploitation and availability of suitable environmental conditions for regeneration (Rey et al. 2000).

\section{Important value index (IVI)}

High density and frequency coupled with high basal area indicate the overall dominance or high importance of the species for the site (Lamprecht 1989). Species with high IVI in the present study were different from other woodland vegetation studied in Dello Menna woodland (Didita et al. 2010), dryland vegetation of Welo (Tadesse et al. 2008); but there was some extent of similarities with a species found in woodland vegetation of Gambela region (Awas et al. 2001), Metema and Abergele dry woodlands (Eshete et al. 2011) and Dawsura-Temben by Woldu et al. (2019). This was associated with the topographic gradients and geographical distribution of the species (Clark et al. 1998; Whittaker et al. 2003). Species with high IVI (> 9) values including Anogeissus leiocarpa, Combretum hartmannianum, Ziziphus spina-christi, Terminalia macroptera, Acacia polyacantha, Flueggea virosa, and Dodonaea angustifolia were the most abundant, dominant, and frequent species in the Hirmi woodland vegetation. On the other side, species such as Cordia Africana, Olea europaea, Otostegia fruticosa, Phytolacca dodecandra, Buddleja cordata, and Acacia nilotica that were scored least IVI $(<0.5)$ also were found rarely and restricted to some sites of the study woodland vegetation. The variability of IVI values of the species within the woodland vegetation attributes the conservation status of some of the highly dominant species. IVI reflects the extent of dominance, occurrence and abundance of a given species in relation to other associated species as well as the ecological significance of a given species (Kent 2012).

\section{Regeneration status of Hirmi woodland}

The density of saplings was higher than the density of the seedlings and mature trees/shrubs. Accordingly, the regeneration status of Hirmi woodland is categorized as poor, following the assessment methods set by Khan et al. (1987). Dryland vegetation of Ethiopia is characterized by poor and fluctuating patterns of regeneration status due to periodic disturbances (Yebeyen 2006; Tesfaye 2008; Lemenih and Bongers 2011). Frequent signs of disturbances were recorded in the community types near the settlement and edge of the Hirmi vegetation. The ordination result also proves that disturbance was significantly associated with the most identified communities (community numbers 1,2 , and 5). Land use/ land cover dynamics study conducted by Gebrelibanos and Assen (2015) and land use/land cover mapping done by Girma (2014) indicated that human settlements around the present study area were restricted to mountainous landmasses. However, the rapid human population growth from time to time imposed settlement in lowland areas for the demand of large farmland as well as plant and plant products. Thus, the massive introduction of humans and livestock in those areas led to poor regeneration of species. As a result, many species were represented with few/no seedlings or saplings. Moreover, species such as Acacia nilotica, Clerodendrum myricoides, Cordia africana, Justicia schimperiana, Phoenix reclinata, and Phytolacca dodecandra were with no seedlings and saplings. A study conducted by Kelbessa and Girma (2011) reported that human-caused disturbances including intensive grazing, fire, and removal of trees are common threats for the regeneration of dryland vegetation. Therefore, species either with no or few 
seedlings and saplings (Table 6) require conservation priority. Research programs focusing on these species should be a priority as well.

\section{Conclusion}

The Hirmi woodland is dominated by undifferentiated floristic composition that belongs to Combretum-Terminalia and Acacia-Commiphora woodland vegetation types with a small section of DAF vegetation types in the elevated areas. Topographic variation of the study area leads to the present heterogeneous vegetation type and structure. In the study vegetation, the dominance of families Fabaceae, Poaceae, Asteraceae, and Lamiaceae agrees with the fact that they are also species-rich families in the country. Furthermore, the presence of 171 species and also 9 endemic and near-endemic species indicates the area's potential of plant diversity and conservation priority. The multivariate analysis displays the identified five plant communities in the study area that were influenced by altitude, slope, total nitrogen, soil organic matter, sand, silt, and disturbance. The high density of species at the lower DBH class and height class is due to the dominance of shrubs or/and the presence of species in the secondary vegetation species such as Dodonaea angustifolia, Flueggea virosa, Diospyros mespiliformis, Ziziphus mucronata, and Maytenus arbutifolia. There is a high degree of floristic heterogeneity, as reflected by the presence of a large number of species in the lower frequency classes. The assessment for the regeneration status of species in the study area showed that the population of saplings was higher than seedlings and mature trees/shrubs. This indicates that the Hirmi woodland has a poor regeneration status which is associated with various disturbance events. Due to the observed multiple disturbance factors (cutting, grazing, fire, and charcoal production signs), Hirmi woodland was found with plant species either with no seedlings, saplings, or both seedlings and sapling. Acacia nilotica, Clerodendrum myricoides, Cordia africana, Justicia schimperiana, Phoenix reclinata, and Phytolacca dodecandra were among the species found under alarming extinction status and with no seedlings and saplings. Therefore, we underscore the immediate need for conservation measures in Hirmi woodland vegetation by considering the identified significant environmental factors associated with the species diversity (altitude, slope, disturbance, soil organic matter, total nitrogen, sand and silt soil type), IUCN threat status and regeneration status of the species.

\section{Supplementary information}

Supplementary information accompanies this paper at https://doi.org/10. 1186/s13717-020-00257-2.

Additional file 1.

\section{Abbreviations}

BA: Basal area; DBH: Diameter at breast height; CBD: Convention on biological diversity; CCA: Canonical correspondence analysis; DAF: Dry evergreen Afromontane forest; DBH: Diameter at breast height;

EFAP: Ethiopian Forestry Action Program; IUCN: International Union for the Conservation of Nature; m.a.s.l: meter above sea level; MEF: Ministry of Environment and Forest; NMSAE: National Metrological Service Agency of Ethiopia; REDD+: Reduced emission from degradation and deforestation

\section{Acknowledgements}

The first author acknowledges the Ministry of Mining and Petroleum for permission to start his Ph.D. study. The financial support from the Rufford Foundation and Addis Ababa University is highly acknowledged. We are grateful to all staff of the Shire Agricultural Research Center for their technical support and field guidance. The staffs of the National Herbarium of Ethiopia are also duly acknowledged. We also thank the local community for their kind support and cooperation while collecting data.

\section{Authors' contributions}

The first (corresponding) author collects and analyzes the data, and wrote the manuscript. The other authors have participated in the formulating of the research as well as analysis, interpreting, and edition of the manuscript. The author(s) read and approved the final manuscript.

\section{Authors' information}

Mehari Girmay is the corresponding author who is a researcher in the Environment and Climate Change Directorate, Ministry of Mining And Petroleum of Ethiopia, P.O. Box 486, Addis Ababa, Ethiopia. Additionally, he is a Ph.D. student in the Department of Plant Biology and Biodiversity Management, Addis Ababa University, P.O. Box 3434, Addis Ababa, Ethiopia. The other three authors (Tamrat Bekele, Sebsebe Demissew, Ermias Lulekal) are staff members of the Department of Plant Biology and Biodiversity Management, Addis Ababa University, P.O. Box 3434, Addis Ababa, Ethiopia.

\section{Funding}

The study was supported by Rufford small grant (British foundation) and Addis Ababa University.

\section{Availability of data and materials}

The datasets generated during and/or analyzed during the current study are available from the corresponding author on reasonable request.

Ethics approval and consent to participate Not applicable.

Consent for publication

All authors have agreed to publish this manuscript.

\section{Competing interests}

The authors declare that they have no competing interests.

Received: 21 May 2020 Accepted: 7 September 2020

Published online: 12 October 2020

\section{References}

Abebe Y (2010) A glimpse at biodiversity hotspots of Ethiopia: the essential directory for environment and development. Ethiopian Wildlife and Natural History Society, Addis Ababa, pp 1-94

Adamu H, Bekele T, Dalle G (2012) Plant community and ecological analysis of woodland vegetation in Metema Area, Amhara National Regional State, Northwestern Ethiopia. J Forestry Res 23:599-607

Agriculture and Natural Resource Bureau of North-Western Zone of Tigray, Ethiopia Annual Report 2017

Arponen A (2012) Prioritizing species for conservation planning. Biodivers Conserv 21(4):875-893

Awas T, Bekele T, Demissew S (2001) An ecological study of the vegetation of Gambella Region, southwestern Ethiopia. SINET: Ethiop J Sci 24:213-228

Aynekulu E (2011) Forest diversity in fragmented landscapes of northern Ethiopia and implications for conservation. Doctoral Dissertation, University of Bonn

Bekele T (1993) Vegetation ecology of remnant Afromontane forests on the central plateau of Shewa, Ethiopia. Acta Phytogeographica Suecica 79:1-64 
Bekele T (1994) Phytosociology and ecology of a humid Afromontane forest on the central plateau of Ethiopia. J Veg Sci 5:87-98

ter Braak CJF (1987) The analysis of vegetation-environment relationships by canonical correspondence analysis. Vegetatio 69:69-77

Braun-Blanquet J (1964) Pflanzensoziologie. Springer, Wien

Brinkmann K, Patzelt A, Dickhoefer U, Schlecht E, Buerkert A (2009) Vegetation patterns and diversity along an altitudinal and a grazing gradient in the Jabal al Akhdar mountain range of northern Oman. J Arid Environ 73:1035-1045

Brooks TM, Mittermeier RA, Mittermeier CG (2002) Habitat loss and extinction in the hotspots of biodiversity. Conserv Biol 16:909-923

Brown RB (2003) Soil Texture. University of Florida, Institute of Food and Agriculture Science. Semantic Scholar, University of Florida, pp 1-8

CBD (2006) Report of the eighth meeting of the Parties to the Convention on Biological Diversity UNEP/CBD/COP/8/31, Curitiba

Clark DB, Clark DA, Read JM (1998) Edaphic variation and the mesoscale distribution of tree species in a Neotropical rain forest. J Ecol 86:101-112

Dale G (2004) Vegetation Ecology, Rangeland Condition and Forage Resources Evaluation in the Borana Lowlands, Southern Oromia, Ethiopia. Doctoral Dissertation. Georg-August University, Göttingen

Vieira DLM, Scariot A, Holl KD (2006) Effects of habitat, cattle grazing and selective logging on seedling survival and growth in dry forests of Central Brazil. Biotropica 39:269-274

Dibaba A, Soromessa T, Kelbessa E, Tilahun A (2014) Diversity, structure and regeneration status of the woodland and riverine vegetation of Sire Beggo in Gololcha District, Eastern Ethiopia. Momona Ethiop J Sci 1:70-96

Didita M, Nemomissa S, Woldemariam T (2010) Floristic and structural analysis of the woodland vegetation around Dello Menna, Southeast Ethiopia. J Forestry Res 21:395-408

EFAP (1994) The Challenge for Development, Volume II. Ethiopian Forestry Action Program, Addis Ababa, Ethiopia

Eshete A, Sterck F, Bongers F (2011) Diversity and production of Ethiopian dry woodlands explained by climate- and soil-stress gradients. Forest Ecol Manag 261:1499-1509

Field R, Hawkins BA, Cornell HV, Currie DJ, Diniz-Filho J, Alexandre F, Guégan JF, Kaufman DM, Kerr JT, Mittelbach GG, Oberdorff T, O'Brien EM, Turner JR (2009) Spatial species-richness gradients across scales: a meta-analysis. J Biogeogr 36:132-147

Friis I (1992) Forests and forest trees of northeast tropical Africa: Their natural habitats and distribution patterns in Ethiopia, Djibouti and Somalia. Her Majesty's Stationery Office, London

Friis I, Demissew S, von Breugel P (2010) Atlas of Potential Vegetation of Ethiopia. The Royal Danish Academy of Science and Letters, Copenhagen

Gaston KJ (2000) Global patterns in biodiversity. Nature 405:220-227

Gebrehiwot K, Demissew S, Woldu Z, Fekadu M, Desalegn T, Teferi E (2019) Elevational changes in vascular plants richness, diversity, and distribution pattern in Abune Yosef mountain range, Northern Ethiopia. Plant Diver 41: $220-228$

Gebrelibanos T, Assen M (2015) Land use/land cover dynamics and their driving forces in the Hirmi watershed and its adjacent agroecosystem, highlands of Northern Ethiopia. J Land Use Sci 10(1):81-94

Georgis K (2010) Agricultural Based Livelihood Systems in Drylands in the Context of Climate Change. Inventory of Adaptation Practices and Technologies of Ethiopia. Food and Agriculture Organization of the United Nations, Rome, pp 5-57

Girma A (2014) Land use land cover mapping of PFM (participatory forest management) project areas and adjacent Sustainable Land Management Program watersheds in three regions of Ethiopia. Mekelle University and GIZ

Hadera G (2000) A study on the ecology and management of the Dessa forest in the northeastern escarpment of Ethiopia. M.Sc. Thesis, Addis Ababa University

Hagos F, John P, Gebreselassie N (1999) Land degradation in the highlands of Tigray and strategies for sustainable land management. Socio-Economic and Policy Research Working Paper 5:2-12

Kelbessa E, Girma A (2011) Forest types in Ethiopia: status, potential contribution and challenges. Forum for Environment, Addis Ababa, 7:4-158

Kent M (2012) Vegetation description and data analysis: a practical approach. 2nd ed. John Wiley \& Sons, New York: 1-30

Khan ML, Rai JP, Tripathi RS (1987) Population structure of some tree species in disturbed and protected subtropical forests of northeast India. Acta Oecologica: Oecologia Applicata 8:247-255
Kooch Y, Jalilvand H, Bahmanyar MA, Pormajidian MR (2009) Differentiation of ecosystem units of Caspian lowland forests and its relation with some soil characteristics. J Iranian Natural Res 62:93-107

Lamprecht H (1989) Silviculture in the tropics: tropical forest ecosystems and their tree species - possibilities and methods for their long-term utilization. TZ-Verlag, Germany

Landon JR (1991) Tropical soil manual: A Handbook for Soil Survey and Agricultural Land Evaluation in the Tropics and Subtropics. Longman Scientific and Technical, Essex, New York, pp 433-474

Lemenih M, Bongers F (2011) Dry forests of Ethiopia and their silviculture. Trop Forestry 8:261-272

Lemessa D (2009) Woody plant species diversity of Taltalle woodland (AcaciaCommiphora woodland ecosystem), Oromia, Ethiopia. Forest Genetic Resources Conservation, Institute of Biodiversity Conservation, Addis Ababa, Ethiopia

Lepš J, Šmilauer P (2001) Multivariate Methods of Ecological Data Analysis using CANOCO. Cambridge University Press, Cambridge, UK, pp 1-283

Lovett JC, Wasser SK (1993) Biogeography and ecology of the rain forests of eastern Africa. Cambridge University Press, Cambridge, UK

Lulekal E, Kelbessa E, Bekele T, Yineger H (2008) Plant species composition and structure of the Mana Angetu moist montane forest, Southeastern Ethiopia. J East African Natural History 97:165-185

Lyaruu HV, Eliapenda S, Backeus I (2000) Floristic, structural and seed bank diversity of dry Afromontane forest at Mafai, central Tanzania. Biodivers Conserv 9:241-263

Magurran AE (1988) Ecological diversity and its measurement. Chapman and Hall, London

Magurran AN (2004) Measuring Biological Diversity. Blackwell Science Ltd, Melden, Mass

Mayaux P, Holmgren P, Achard F, Eva H, Stibig H, Branthomme A (2005) Tropical forests cover change in the 1990s and options for future monitoring. Philos Trans R Soc 360:373-384

McCune B, Grace JB (2002) Analysis of Ecological Communities. MjM Software Design, Oregon, USA, pp 301-304

MEF (2015) Pilot Redd+ Sites Visit Report. Federal Democratic Republic of Ethiopia, Addis Ababa

Mengistu T, Teketay D, Hultenc H, Yemshaw Y (2005) The role of enclosures in the recovery of woody vegetation in degraded dryland hillsides of central and northern Ethiopia. J Arid Environ 60:259-281

Mueller-Dumbois D, Ellenberg H (1974) Aims and Methods of Vegetation Ecology. Wiley, New York

Murphy PG, Lugo AE (1986) Ecology of tropical dry forest. Annu Rev Ecol Syst 17: $67-88$

Muys B, Gebrehiwot K, Aerts R, Haile M, Deckers J (2006) Perspectives for the rehabilitation of dryland forests in Ethiopia. J Drylands 1:217-220

NMSAE (2018) Data of Rainfall and Temperature of 20 years (1998-2017). Addis Ababa

Nyssen J, Unro M, Haile M, Poesen J, Descheemaeker K, Haregeweyn N, Oeyersons J, Govers G, Deckers J (2007) Understanding the environmental changes in Tigray. Mekelle University IUC Programme and Zala-Daget Project $3: 2-82$

O'Geen AT, Elkins R, Lewis D (2006) Erodibility of agricultural soils, with examples in Lake and Mendocino counties. Oakland: University of California Division of Agriculture and Natural Resources publication 8194. http://anrcatalog.ucdavis edu

Pimm L, Raven P (2000) Extinction by numbers. Nature 403:843-845

R Development Core Team (2019) R: A Language and Environment for Statistical Computing. http://www.r-project.org/

Rey PJ, Julio M, Alcantara M (2000) Recruitment dynamics of a fleshy-fruited plant (Olea europaea): connecting patterns of seed dispersal to seedling establishment. J Ecol 88:622-633

Senbeta F, Teketay D (2001) Regeneration of indigenous woody species in native and exotic tree plantations in central Ethiopia. J Trop Ecol 42:175-185

Senbeta F, Woldemariam T, Demissew S, Denich M (2007) Floristic diversity and composition of Sheko forest, southwest Ethiopia. Ethiopian J Biol Sci 6:11-42

Sertsu S, Bekele T (2000) Procedures for soil and plant analysis. National Soil Research Centre, Ethiopian Agricultural Research Organization, Addis Ababa, Ethiopia

Ruwanza S (2018) The edge effect on plant diversity and soil properties in abandoned fields targeted for ecological restoration. Sustainability 11:140 
Suratman MN (2012) Tree Species Diversity and Forest Stand Structure of Pahang National Park, Malaysia. In: Lameed AG (ed.) Biodiversity Enrichment in a Diverse World: $45-56$

Swaine MD, Lieberman D, Hall JB (1990) Structure and dynamics of a tropical dry forest in Ghana. Vegetatio 88:31-51

Tadesse M (2004) Asteraceae (Compositae). In: Hedberg I, Friis IB, Edwards S (eds.) Flora of Ethiopia and Eritrea. Volume 4, part 2. The National Herbarium, Addis Ababa University, Uppsala, p 408

Tadesse Z (2015) Floristic Composition and Structural Analysis of Woodland Vegetation in Ilu Gelan District, West Shewa Zone of Oromia Region, Central Ethiopia. MSc thesis in Biology (Botanical Science), Addis Ababa University, Addis Ababa

Tadesse G, Bekele T, Demissew S (2008) Dryland woody vegetation along an altitudinal gradient on the eastern escarpment of Wolo, Ethiopia. SINET: Ethiop J Sci 31:43-54

Tadesse Z, Kelbessa E, Bekele T (2018) Structural analysis of CombretumTerminalia mixed Acacia vegetation in Ilu Gelan District, West Shewa Zone, Oromia Region, Central Ethiopia. Tropical Plant Res 5:61-76

Teketay D (2001) Deforestation, wood famine, and environmental degradation in Ethiopia's highland ecosystems: urgent need for action. Northeast Afr Stud 8: 53-76

Tenkir E (2006) Soil seed bank study and natural regeneration assessment of woody species in Dodola dry afromountain forest and Bale Mountains. MSC thesis in Biology (Botanical Science), Addis Ababa University, Addis Ababa

Tesfaye $G$ (2008) Ecology of regeneration and phenology of seven indigenous tree species in a dry tropical Afromontane forest, southern Ethiopia. Ph.D. dissertation, Addis Ababa University, Addis Ababa, Ethiopia

Tilahun A, Soromessa T, Kelbessa E, Dibaba A (2011) Floristic composition and community analysis of Menagesha Amba Mariam forest (egdu forest) in central shewa, Ethiopia. Ethiopian J Biol Sci 10:111-136

Tuxill J, Nabhan GP (2001) People, plants and protected areas. Earthscan Publication Ltd, London and Sterling, p 248

Van der Maarel E (1979) Transformation of cover-abundance values in phytosociology and its effects in community similarity. Vegetatio 39:97-114

Vivero JL, Kelbessa E, Demissew S (2005) The Red List of Endemic Trees \& Shrubs of Ethiopia and Eritrea. Fauna \& Flora International, United Kingdom, p 28

White $F$ (1983) The vegetation of Africa: A descriptive memoir to accompany the vegetation map of Africa. UNESCO, Switzerland, p 353

Whittaker RJ, Willis KJ, Field R (2003) Climatic-energetic explanations of diversity: a macroscopic perspective. In: Blackburn TM, Gaston KJ (eds.) Macroecology: concepts and consequences. Cambridge University Press, Cambridge, pp $107-129$

Woldu Z (2016) Comprehensive analysis of vegetation and ecological data: Basics, concepts and methods. Addis Ababa University Press, Addis Ababa, pp 1-40

Woldu Z, Feoli E, Nigatu L (1989) Partitioning an elevation gradient of vegetation from southeastern Ethiopia by probabilistic methods. Vegetatio 81:189-198

Woldu G, Solomon N, Hishe H, Gebrewahid H, Amha M, Birhane E (2019) Topographic variables to determine the diversity of woody species in the exclosure of Northern Ethiopia. Heliyon 6:1-6

Yebeyen D (2006) Population status of Acacia senegal (Linne) Wild and its gum quality in the central Rift Valley of Ethiopia. MSc. thesis, Wondo Genet College of Forestry, Ethiopia

Yineger H, Kelbessa E, Bekele T, Lulekal E (2008) Floristic composition and structure of the dry Afromontane forest at Bale Mountains National Park. SINET: Ethiopian J Sci 31:103-120

Yismaw A, Gedif B, Addisu S, Zewudu F (2014) Forest cover change detection using remote sensing and GIS in Banja district, Amhara region, Ethiopia. Int J Environ Monit Analy 2:354-360

\section{Publisher's Note}

Springer Nature remains neutral with regard to jurisdictional claims in published maps and institutional affiliations.

\section{Submit your manuscript to a SpringerOpen ${ }^{\circ}$ journal and benefit from:}

- Convenient online submission

- Rigorous peer review

- Open access: articles freely available online

- High visibility within the field

- Retaining the copyright to your article

Submit your next manuscript at $\boldsymbol{\nabla}$ springeropen.com 